\title{
Öğretmen Adaylarının Bilgi ve İletişim Teknolojileri (BİT) Yeterlikleri: Ondokuz Mayıs Üniversitesi Örneği*
}

\author{
Preservice Teachers' Competence of Information and \\ Communication Technologies: Sample of Ondokuz Mayıs \\ University
}

\author{
Mücahit AYDOĞMUŞ**, Yıldıray KARADAĞ***
}

\begin{abstract}
Öz: Bilgi ve iletişim teknolojileri birçok alanda olduğu gibi eğitimde de önemini giderek artırmaktadır. Bilgi ve iletişim teknolojileri ile desteklenen eğitim ortamlarının öğrencilerin bilişsel ve duyuşsal becerilerini olumlu etkilediği görülmektedir. Dolayısıyla geleceğin öğretmenlerinin bilgi ve iletişim teknolojileri yeterliklerinin incelenmesinin değerli olduğu düşünülmektedir. Araştırmanın amacı öğretmen adaylarının bilgi ve iletişim teknolojileri yeterliklerinin incelenmesidir. Araştırmada tarama modeli kullanılmıştır. Veriler kolay ulaşılabilir durum örneklemesi kullanılarak sınıf ve sosyal bilgiler öğretmenliği bölümlerinde okuyan 310 öğretmen adayındantoplanmıştır. Veri toplama aracı olarak "Öğretmen Adayları için Bilgi ve İletişim Teknolojileri YeterlikleriÖlçeği” kullanılmıştır. Verilerin analizinde betimsel istatistiksel yöntemler, t-testi ve tekyönlü varyans analizi teknikleri kullanılmıştır. Analizler sonucunda öğretmen adaylarının ölçek genelinde ve bilgi ve iletişim teknolojilerikullanım desteği altfaktöründe "yüksek düzeyde", öğretim tasarımına yönelikbilgi ve iletişim teknolojileri alt faktöründe ise "orta düzeyde" yeterliliğe sahip olduğu tespit edilmiştir. Bölüm ve bilgisayar sahibi olma değişkenlerinin öğretmen adaylarının bilgi ve iletişim teknolojileriyeterliklerini etkilemediği sonucuna ulaşılmıştır. Cinsiyet değişkeninde bilgi ve iletişim teknolojilerikullanım desteğialt faktöründe erkek öğretmen adayları lehine anlamlı farklılık olduğu tespit edilmiştir. Sınıf düzeyi değişkeninde toplam ölçek ve alt faktörlerde 4. sınıf öğretmen adayları lehine anlamlı farklılık olduğu sonucuna ulaşılmıştır. Bilgi ve iletişim teknolojilerineyönelik seminer veya kurslara katılma değişkeninde toplam ölçek genelinde ve bilgi ve iletişim teknolojilerikullanım desteği alt faktöründe seminer veya kurslara katılan öğretmen adayları lehine anlamlı farklılıklar olduğu tespit edilmiştir. Öğretmen adaylarının bilgi ve iletişim teknolojileriyeterliklerini artırmak adına yapılan seminer veya kurs programlarının sayılarının artırılması önerilebilir.
\end{abstract}

Anahtar Kelimeler: Bilgi ve iletişim teknolojileri, öğretmen adayları, bilgi teknolojileri, BİT yeterliği

\begin{abstract}
Information and communication technologies gradually increase their importance in education as in many fields. It is seen that educational environments supported by information and communication technologies affect students' cognitive and affective skills positively. Therefore, it is considered worthy to examine the information and communication technologies competencies of preservice teachers. The aim of this study was to determine preservice teachers' information and communication technologies (ICT) competence. Survey model was used in research.The data of the research were collected by using easily accessible case sampling andwere obtained from 310 preservice teachers studying in classroom and social studies teaching departments.Data were collected using the Information and Communication Technology Competencies Scale for Preservice Teachers(ICTC-PT).Data were analyzed using descriptive statistical methods, t-test and one-way variance analysis techniques. Participants had a high total score from ICTCPTand competencies to support pupils for ICTuse in class (CSP-ICT) subscale score whereas they had a moderate competency to use ICT for instructional design (ICT-ID) subscale score. Their scores did not significantly differ by major department and computer ownership. Male participants had significantly higher CSP-ICT scores than females. Fourth graders had significantly higherCSP-ICT scores than other

\footnotetext{
* Bu çalışma 7-9 Kasım 2019 tarihlerinde Ankara'da gerçekleştirilen 8. Uluslararası Sosyal Bilgiler Eğitimi Sempozyumu'nda sözlü bildiri olarak sunulmuştur.

** Arş. Gör., Ondokuz Mayıs Üniversitesi, Eğitim Fakültesi, Samsun-Türkiye, ORCID: 0000-0002-1418-1100, eposta: mucahit.aydogmus@omu.edu.tr

*** Arş. Gör., Ondokuz Mayıs Üniversitesi, Eğitim Fakültesi, Samsun-Türkiye, ORCID: 0000-0002-0336-7815, eposta: yildiray.karadag@omu.edu.tr
} 
graders. Those who had attended seminars or courses on ICT had higher ICTC-PT and CSP-ICT scores than those who had not. It is recommended that undergraduate students of teaching departments be offered more seminars or course programs to help them develop ICT competencies.

Keywords: Information and communication technologies, preservice teachers, information technologies, ICT competencies.

\section{Giriş}

Bilgi ve iletişimteknolojilerininöğretim programlarında yer alması, okulların ve sınıfların gerekli alt yapı ile donatılması ve öğretmen ve öğrencilerin bilgi ve iletişim teknolojilerinietkili bir şekilde kullanmaları eğitim öğretim faaliyetlerinin niteliği üzerindeki etkileri bakımından değerli görülmektedir. Bilgi teknolojileri "bilginin toplanmasını, işlenmesini ve saklanmasını, herhangi bir yere iletilmesini, herhangi bir yerden bu bilgiye erişilmesini, elektronik vb. yollarla sağlayan teknolojiler bütünü” olarak tanımlanmaktadır (Türk Dil Kurumu, 2020). İletişim teknolojisi ise insanlar arasında haberleşme ve iletişim süreci içerisinde kullanılan telefon, televizyon, faks, bilgisayar ve internet gibi araçların tamamı olarak tanımlanmaktadır (United Nations Educational Scientific and Qultural Organization, 2003). Bilgiye ulaşmak için kullanılan teknolojiler iletişim amacıyla da kullanıldığı ve iletişim sürecinde insanlar arasında transfer edilen her şey bilgi olarak nitelendirilebileceği için bilgi teknolojisi ve iletişim teknolojisi kavramları bir arada kullanılmaktadır. Buradan hareketle bilgi ve iletişim teknolojileri; bilginin iletilmesi, depolanması, saklanması, üretilmesi, düzenlenmesi, çoğaltılması ve paylaşılması için kullanılan araç, gereç ve ortamların tamamı olarak tanımlanabilir.

Bilgi ve iletişim teknolojileriningünlük hayatın her alanında çeşitli yansımalarının var olması günümüz bireylerinin bilgi ve iletişim teknolojilerikullanımı konusundaki becerilerinin geliştirilmesi gerekliliğini ortaya çıkarmaktadır (Şad ve Nalçacı, 2015). Çünkü bilgi ve iletişim teknolojilerinin hayatta karşılaşılan problemleri çözmede ve sosyal çevre ile olan etkileşimde önemli bir araç olduğu düşünülmektedir (Sime ve Priestly, 2005). Bireylerin bilgi ve iletişim teknolojilerinietkili kullanabilecek niteliğe ulaşmasında birçok unsur vardır ancak bunların en önemlilerinden biri eğitim kurumlarıdır (Berkyürek, 2008; Demirhan, 2012; Eryılmaz, 2018; Göktaş, Yıldırım ve Yıldırım, 2008; Şad ve Nalçac1, 2015). Okul öncesi dönemden yükseköğretime kadar olan örgün eğitim süreci düşünüldüğünde öğrencilerin eğitim kurumları ile olan etkileşimlerinin uzun bir süreyi kapsadığı söylenebilir. Dolayısıyla bireylerden, eğitim sürecinin sonunda diğer bir dizi bilgi ve beceri ile birlikte bilgi ve iletişim teknolojilerialanındaki bilgi ve becerileri de kazanmaları beklenmektedir. Bir başka ifadeyle; eğitim kurumları toplumun ihtiyaçlarına uygun olarak, öğrencileri bilgi toplumuna hazırlamak ve bilgi toplumu bireylerinin sahip olması gereken bilgi ve iletişim teknolojileriyeterliklerini kazandırmakla yükümlüdür (Özel, 2010).

Bilgi ve iletişim teknolojilerine yönelik eğitim kurumlarında yapılan çalışmalarda en büyük görev öğretmenlere düşmektedir (Hew ve Leong, 2011; Kolburan Geçer ve Gökdaş, 2014). Bu nedenle öğretmenlerin bilgi ve iletişim teknolojilerine ilişkin yeterlikleri birçok boyutta önem taşımaktadır. $\mathrm{Bu}$ boyutlar öğretmenlerin; çağdaş yaşam koşullarına uyum sağlamaları ve teknolojide meydana gelen modern yenilik ve değişimleri yakından takip etmeleri, bilgi ve iletişim teknolojilerini öğretim süreçlerine entegre ederek öğretimin niteliğini artırmaya yönelik kullanmaları, ögrencilerin bilgi ve iletişim teknolojilerialanında gerekli olan bilgi ve becerileri kazanmaları için çeşitli uygulamalar ve aktif öğrenme yaşantıları meydana getirmeleri olarak ifade edilebilir. $\mathrm{Bu}$ boyutlar dikkate alındığındaöğretmenler bir yandan bilgi ve iletişim teknolojilerini kendi yaşantılarına adapte etmiş, bir yandan öğrencileri hayata hazırlama misyonunu üstlenen eğitim kurumlarının bu amacına ulaşmasına katkı sağlamış, bir yandan da tüm derslerde teknolojik yenilikleri kullanarak öğrencilerin beklenen akademik kazanımlara ulaşmalarında önemli bir rol oynamış olacaklardır.

Bilgi ve iletişim teknolojilerininöğretim süreçlerine entegrasyonunun; öğrenci başarısını artırdığ 1 , öğrencilerin üst düzey düşünme becerilerini geliştirdiği, eğitimde kaliteyi ve firsat eşitliğini artırdığı görülmektedir (Aypay, 2010; Boshuizen ve Wopereis, 2003; Hernandez Ramos, 2005; Herzig, 2004; Lim ve Ching, 2004; Sanchez, Salinas ve Haris, 2011). Ayn1 
zamanda bilgi ve iletişim teknolojilerinin; geleneksel öğretim yöntemlerini etkili hale getirme, öğrenmelerin kalıcılı̆̆ını artırma, öğrencilerin bireysel farklılıklarına uygun öğretim olanakları sağlama, ögrencilerin derslere yönelik tutumlarını ve motivasyonlarını artırarak derslere aktif olarak katılmalarına imkân tanıma, öğretimi öğrenci düzeyine göre planlama, problem çözme becerisini ve yaratıcılı̆̆ 1 geliştirme, dersler için zengin materyaller sunma, öğrencilerin bilimsel okuryazarlık becerilerinin gelişimine katkı sağlama gibi avantajları bulunmaktadır (Akkoyunlu, 1996; Chou, Hsiao, Shen ve Chen, 2010; Çoklar, 2012; Luu ve Freeman, 2011; Su, 2008). Nitekim Atalay ve Anagün'ün (2014) çalışmalarında elde edilen sonuçlara göre; sınıf öğretmenleri bilgi ve iletişim teknolojilerininöğretimsel hedeflere ulaşmak için kullanılmasının; derse öğrencilerinin ilgilerini çekme ve birden fazla duyuya hitap etme kanalıyla başarıy yükselttiğini, zamanı etkili kullanmaya ve duyuşsal boyutlara da olumlu etki ederek öğrenmede kolaylık sağladığını belirtmektedirler. Fu'ya (2013) göre ise bilgi ve iletişim teknolojilerinin; öğrencilerin dijital bilgilere erişmelerini kolaylaştırdığı, yapılandırmacı eğitim anlayışına uygun olarak öğrenci merkezli öğrenmeyi desteklediği ve öğretimin niteliğini artırdığı görülmektedir. Bununla birlikte bilgi ve iletişim teknolojileri; sadece öğrenci başarısı değil öğretmen başarısını da artırmakta, öğrencilerin derse yönelik ilgilerini de olumlu yönde etkileyerek öğrenmeyi kolaylaştırmaktadır (Cüre ve Özdener, 2008). Bilgi ve iletişim teknolojilerinin yukarıda ifade edilen etkilerinin yanı sıra; dersin planlanması, hazırlık süreci, dersin yürütülmesi ve değerlendirilmesi aşamalarının tamamında işe koşulabilmesi, öğretmenlere öğretim sürecinde büyük faydalar sağlamaktadır (Uluğ, 2000). Bu durum öğretmenlerin bilgi ve iletişim teknolojileriyeterliklerinin istenilen düzeyde olması için birtakım çalışmaların yapılması gerektiğgini ortaya koymaktadır. Çünkü öğretmenlerden bilgi ve iletişim teknolojileriile ilgili farklı becerileri kazanmaları beklenmektedir. Türkiye ve dünyada, öğretmenlerin teknolojiyi etkili bir şekilde kullanmaları, bilişim teknolojilerini öğrenme ortamına adapte edebilmeleri ve eğitimin her alanında teknolojinin imkânlarını kullanarak öğretimin niteliğini artırmaya yönelik faaliyetleri yürütebilmelerini sağlamak amacıyla bilgi ve iletişim teknolojileriyeterliklerini geliştirmeye yönelik çeşitli çalışmalar yapılmaktadır. Dolayısıyla bilgi ve iletişim teknolojileri; ilköğretim, ortaöğretim, yükseköğretim ve özellikle öğretmen yetiştirmede üzerinde çalışllan önemli bir yeterlik alanı olarak ortaya çıkmaktadır.

Öğretmen yetiştirme politikaları çerçevesinde Uluslararası Eğitimde Teknoloji Topluluğu (ISTE); bilgi ve iletişim teknolojilerialanında öğretmenlerden, teknoloji okuryazarlı̆̆ derslerde teknolojiden faydalanabilme ve ögrencileri teknolojiyi kullanmaya teşvik edebilme gibi becerileri kazanmış olmalarının beklenildiğini ifade etmektedir (International Society for Technology in Education, 2020). Ayrıca 'Öğretmenlik Mesleği Genel Yeterlikleri'nde; öğretmenlerde bulunması gereken yeterliklerden biri "öğretme ve öğrenme sürecinde bilgi ve iletişim teknolojilerini etkin olarak kullanır" ifadesiyle açıklanmıştır (Millî Eğitim Bakanlığı, 2017). Bununla birlikte Öğretmen Yetiştirme Lisans Programları'nda öğretmen adaylarından bilişim teknolojisine ilişkin bilgi ve becerilere sahip olmalarının beklendiği ifade edilerek; 2018 yılında eğitim fakültesi ögretmen yetiştirme lisans programlarında yapılan güncelleme ile birlikte öğretmen adaylarının bilgi ve iletişim teknolojilerialanındaki bilgi ve becerilerini geliştirmek amacıyla yirmi beş öğretmenlik branşının tamamında "bilişim teknolojileri" dersi; bilgi ve iletişim teknolojilerini öğretim süreçlerine entegre edebilme becerilerini kazandırmak ve geliştirmek için de "öğretim teknolojileri” dersi zorunlu dersler olarak programlarda yer almaktadır. Ayrıca derslerin içerikleri incelendiğinde meslek bilgisi ve alan eğitimi dersleri başta olmak üzere derslerin büyük çoğunluğunda bilgi ve iletişim teknolojileri kullanımına vurgu yapıldığı görülmektedir. (Yükseköğretim Kurulu, 2018).

Öğrenci ve öğretmenler başta olmak üzere eğitim sisteminden bilgi ve iletişim teknolojileriile ilgili beklenen yeterliklere erişilmesi için üç önemli gereklilik bulunmaktadır. Bunlardan ilki, bilgi ve iletişim teknolojileriile ilgili uygulamalı ve yaşantıya dayalı bir öğretim süreci yürütülebilmesi için fiziki ve teknik alt yapının amaçlara ulaşmak için uygun ve hazır olması; ikincisi öğretmenlerin var olan alt yapı elemanlarını etkili bir şekilde kullanabilme ve bilgi ve iletişim teknolojilerini eğitime entegre edebilme becerilerini kazanmış olmaları; üçüncüsü ise öğretmenlerin, öğrencileri bilgi ve iletişim teknolojilerini aktif ve eleştirel bakış açısıyla 
kullanmaları için bilinçlendirme ve teşvik edebilme yetkinliğine sahip olmaları gerekliliğidir. Teknolojik alt yapı ile ilgili durum dikkate alındığında özellikle Fırsatları Artırma ve Teknolojiyi İyileştirme Hareketi (FATİH Projesi) kapsamında 2017 yılı itibariyle 432.288 etkileşimli tahtanın dersliklere kurulduğu, 1.437.800 tabletin öğrenci ve öğretmenlere dağıtıldığı, 325.883 derslikte ağ alt yapısı kurulumu gerçekleştirildiği görülmektedir (Millî Eğitim Bakanlığı, 2018). 2018 yılında ise Türkiye'deki okullarda hedeflenen internet alt yapısı, tablet veya etkileşimli tahta kurulum oranının \%59,31'e ulaştığı ve 2019 yılında bu oranın \% 100'e çıkarılmasının amaçlandığ ifade edilmektedir (Milli Eğitim Bakanlığ1, 2019). Toplam ülke nüfusunun \%75,3'ünün internet kullandığg; hanelerde internet erişim olanaklarının \%88,3'e ulaştığ 1 , bilişim teknolojine sahip olma durumları açısından Türkiye'deki hanelerin \%17,6'sında masaüstü bilgisayar, \%37,6'sında dizüstü bilgisayar, \%26,7'sinde tablet, \%37'sinde internete bağlanabilen televizyon ve $\% 98,7$ 'sinde akıllı telefona sahip olunduğu görülmektedir (Türkiye İstatistik Kurumu, 2019). Buradan hareketle öğrencilerin ve öğretmenlerin bilgi ve iletişim teknolojileribecerilerini geliştirmeleri için gerekli olan alt yapı ile ilgili gerek okul içi gerekse okul dışı ortamlarda yeterli olanaklara sahip oldukları söylenebilir. Ancak bu olanaklar bilgi toplumuna öğrenci ve öğretmen yetiştirme konusunda tek başına yeterli olamamaktadır. Nitekim teknolojik alt yapı ve araç gereçlerle donatılmış eğitim öğretim ortamları bu araçları etkili bir şekilde kullanma becerilerine sahip olan öğretmenlerle anlam kazanmaktadır.

Öğretmenlerin var olan alt yapı olanaklarını etkili bir şekilde kullanabilme; bilgi ve iletişim teknolojilerini eğitime entegre edebilme ve öğrencileri bilgi ve iletişim teknolojileri kullanımı konusunda bilinçlendirme becerilerini kazanmış olmaları açısından bakıldığında ise öğretmen yetiştirme ve öğretmen eğitimi ön plana çıkmaktadır. Çünkü öğretmenlerin derslerinde teknolojiyi etkin kullanabilmeleri, öncelikle pedagojik bilgilerle bütünleştirilmiş bir eğitim almalarına bağlıdır. Öğretmenlerin bu bilgi ve becerileri kazanabilmeleri için hizmet öncesi ve hizmet içi eğitim süreçlerine odaklanılması gerektiği söylenebilir. Türkiye'de yürütülen hizmet içi eğitim etkinliklerinin niceliği, niteliği, eğitime katılma olanağına sahip olan öğretmen sayısı dikkate alındığında; hizmet içi eğitim uygulamalarının yeteri kadar öğretmene verilemediği, hizmet içi eğitim programlarının azlığ1 ve var olan hizmet içi eğitim etkinliklerinin beklenen katkıyı sağlamakta yetersiz kaldığı söylenebilir (Avşar, 2011; Ayvacı, Bakırcı ve Yıldız, 2014; Göksoy, 2014; Güney, 2018, Kahyaoğlu ve Karataş, 2019; Karadağ, 2015; Madden, 2003). Hizmet içi eğitimlerle ilgili var olan bu gerçeklik öğretmenlere bilgi ve iletişim teknolojileriyeterliklerinin kazandırılmasında hizmet öncesi eğitim süreçlerinin daha kritik rol oynadığını göstermektedir. Çünkü öğretmen adayları kazanmaları gereken bilgi ve becerileri hizmet öncesi eğitim sürecinde kazanamadıklarında ve öğretmenliğin gerektirdiği yeterliklere bu dönemde sahip olamadıklarında hizmet içi eğitim süreçlerine katılma fırsatı bulsalar bile hizmet içi eğitim süreci bu yeterlikleri kazandırmada etkili olamamaktadır (Koçyiğit ve Eğmir, 2019).

Bilgi ve iletişim teknolojilerialanındaöğretmen adayları ile yapılan çalışmalar dikkate alındığında; teknopedagojik eğitim yeterlikleri ile bilgi ve iletişim teknolojilerikullanımları arasındaki ilişkinin incelendiği (Yurdakul, 2011), bilgisayar yeterlikleri ve teknoloji kullanımı tutumları arasındaki ilişkinin incelendiği (Usta ve Korkmaz, 2010), bilgisayar ve internet kullanma durumlarının araştırıldığı (Birgin, Çoker ve Çatlığlu, 2010), e-öğrenme ile ilgili algılarının ve görüşlerinin belirlenmesinin amaçlandığı (Çobanoğlu, Ateş, İliç ve Yılmaz, 2009; Dikbaş, 2006), bilgi okuryazarlığı ve uzaktan eğitim tutumlarının incelendiği (Özdemir, Akbaş ve Çakır, 2010), bilgisayara karşı tutum ve bilgisayar öz yeterliğinin teknoloji kabulüne etkisinin araştırıldığı (Teo, 2009), bilgi ve iletişim teknolojilerikullanımı yeterlik algılarının incelendiği (Şad ve Nalçacı, 2015) araştırmaların varlığı göze çarpmaktadır.Bu çalışmaların alana farklı yönlerden katkı sağladığı belirtilebilir.Ancak bu araştırmaların,bilgi ve iletişim teknolojileri ile ilgili olmakla beraber öğretmen adaylarının bilgi ve iletişim teknolojileri yeterliklerini doğrudan inceleyen araştırmalar olmadığı ifade edilebilir.Buaraştırmalarda cinsiyet, yaş, sınıf, bölüm, bilsayara sahip olma, bilgisayara erişim, bilgisayar kullanım amacı, internet kullanım amac1, bilgisayar kullanma deneyimi, günlük bilgisayar kullanım süresi gibi değişkenler ele alınmıştır. Bununla birlikte bilgi ve iletişim teknolojileri yeterliklerinin doğrudan ele alındığı Şad ve Nalçacı'nın (2015) araştırmalarında ise cinsiyet, bölüm, bilgisayar sahibi olma ve internet 
kullanma sıklığı değişkenlerinin araştırıldığı görülmektedir. Buradan haraketle bu araştırmada, bilgi ve iletişim teknolojileri ile ilgili farklı boyutları etkileyen değişkenlerin öğretmen adaylarının bilgi ve iletişim teknolojileri yeterliklerini de etkiyebileceği düşünülerek cinsiyet, bölüm, sınıf düzeyi, kendine ait bilgisayara sahip olma, bilgi ve iletişim teknolojilerine yönelik seminer veya kursa katılma durumu değişkenleri ele alınmıştır. Hizmet öncesi eğitim dönemini kapsayan, öğretmen adaylarının bilgi ve iletişim teknolojileri yeterliklerine yönelik alanyazındabulunan çalışmaların azlığı dikkate alınarak; öğretmen adaylarının bilgi ve iletişim teknolojileri yeterliklerini inceleyen bu araştırmanın ilgili alanyazındaki diğer çalışmalardan farklı bir ölçme aracı vasıtasıyla, farklı değişkenler dâhil edilerek gerçekleştirilmesi ve güncel bir çalışma olması yönleriyle önemli olduğu ve alana katkı sağlayacağı düşünülmektedir. Çünkü hizmet öncesi eğitim bilgi toplumunda yaşanan hizlı değişimlere uyum sağlayabilen öğretmenlerin yetiştirilmesi için önemli kazanımların elde edilebileceği bir dönemi ifade etmektedir. Eğitimde başarının sağlanması için eğitim sisteminin en önemli unsurlarından biri olan öğretmenleri hizmet öncesi dönemde yetiştirmeye yönelik etkinliklerin çağın gereklerine göre, toplumun eğitimden beklentisi ile paralel ve öğretmen adaylarını tüm yönleriyle geliştirerek mesleğe hazırlayacak niteliklerde olması gerekmektedir (Millî Eğitim Bakanlığı, 2017). Etkili öğretmenlerin yetiştirilmesi için kasıtlı, planlı ve uygulamalı eğitim süreçlerine ihtiyaç duyulmaktadır (Koçyiğit ve Eğmir, 2019). Bu nedenle öğretmen niteliği ile ilgili yapılacak araştırmaların öğretmen adaylarıyla yürütülmesinin gerekliliği ortaya çıkmaktadır. Dolayısıyla bu araştırma; öğretmen adaylarının bilgi ve iletişim teknolojileriyeterliklerini belirmeyi amaçlayan güncel bir çalışma niteliği taşımaktadır. Araştırma sonuçlarının öğretmen yetiştiren kurumlara, diğer eğitim kurumlarına, yöneticilere ve araştırmacılara önemli dönütler sağlayacağ düşünülmektedir. Ayrıca bu dönütlerin bilgi ve iletişim teknolojilerikonusunda bilgi, beceri ve yeterlik sahibi öğretmenlerin yetiştirilmesine yönelik yapılacak iyileştirme ve düzenlemelere katkı sağlayacağı düşünülmektedir. Araştırmada cevapları aranan sorular şunlardır:

- Öğretmen adayların bilgi ve iletişim teknolojilerineilişkin yeterlik düzeyi nedir?

- Öğretmen adaylarının bilgi ve iletişim teknolojileriyeterlikleri;

a) cinsiyet

b) bölüm

c) sinıf düzeyi

d) kendine ait bilgisayara sahip olma durumu

e) bilgi ve iletişim teknolojilerine yönelik seminer veya kursa katılma durumu değişkenlerine göre anlamlı farklılık göstermekte midir?

\section{Yöntem}

\section{Araştırma deseni}

Araştırma nicel araştırma yaklaşımları üzerine tasarlanmış olup tarama modeli (Karasar, 2015) kullanılarak işe koşulmuştur. Tarama modelleri, araştırmacıların daha büyük örneklem grupları üzerinde çalışmalarına olanak sağlayan bir araştırma modelidir (Büyüköztürk, Kılıç Çakmak, Akgün, Karadeniz ve Demirel, 2015). Bu model temel alınarak tasarlanan araştırmalarda, araştırmacılar olayları, bireyleri veya nesneleri herhangi bir şekilde etkilemeye veya değiştirmeye çalışmaz. Bu sayede araştırmaya değer bulunan olay, birey ve nesneler kendi koşulları içinde var olduğu biçimde betimlenir (Karasar, 2015). Bu kapsamda araştırmada öğretmen adaylarının bilgi ve iletişim teknolojileriyeterliklerinin var olduğu şekliyle betimlenmesi adına bu modelin kullanılması uygun görülmüş̧ür.

\section{Çalışma grubu}

Araştırmada amaçlı örnekleme yöntemlerinden kolay ulaşılabilir durum örneklemesi yöntemi kullanılmıştır. Bu kapsamda araştırmanın örneklemi 2019-2020 eğitim öğretim y1lı güz döneminde Ondokuz Mayıs Üniversitesi Eğitim Fakültesi'nde tüm sınıf düzeylerinde öğrenim 
gören 310 sınıf ve sosyal bilgiler öğretmenliği öğrencilerinden oluşmaktadır. Araştırmanın katılımcılarına ilişkin kişisel özellikler Tablo 1'de sunulmuştur.

Tablo 1.

Katılımcıların Kișisel Özellikleri

\begin{tabular}{lcc}
\hline Özellikler & $\mathrm{f}$ & $\%$ \\
\hline Bölüm & 170 & 54,8 \\
Sinıf Öğretmenliğ̈i & 140 & 45,2 \\
Sosyal Bilgiler Öğretmenliği & & \\
\hline Cinsiyet & 230 & 74,2 \\
Kadın & 80 & 25,8 \\
Erkek & & \\
\hline Sinıf Düzeyi & 75 & 24,2 \\
1. Sınıf & 74 & 23,9 \\
2. Sınıf & 82 & 26,5 \\
3. Sınıf & 79 & 25,5 \\
4. Sinıf & & \\
\hline Kendine Ait Bilgisayara Sahip Olma Durumu & 182 & 58,7 \\
Evet & 128 & 41,3 \\
Hayır & 34 & \\
\hline Bilgi ve İletişim Teknolojilerine Yönelik Seminer veya Kursa Katılma a & 11 \\
Evet & 276 & 89 \\
Hayır & 310 & 100 \\
\hline Toplam & & \\
\hline
\end{tabular}

\section{Veri toplama araçları}

Araştırmada iki ayrı bölümden oluşan bir veri toplama aracı kullanılmıştır. Birinci bölümde öğretmen adaylarının bilgi ve iletişim teknolojileriyeterliklerini etkileyebileceği düşünülen bölüm, cinsiyet, sınıf düzeyi, kendine ait bilgisayara sahip olma durumu ve bilgi ve iletişim teknolojilerine yönelik seminer veya kursa katılma durumu değişkenlerine ait kişisel bilgiler yer almıştır. Bu değişkenlerin belirlenmesi sürecinde ilgili alanyazın taranmış ve kişisel bilgi formu öğretmen adaylarının bilgi ve iletişim teknolojileri yeterlikleri üzerinde etkili olabileceği düşünülen değişkenler saptanarak oluşturulmuştur. Veri toplama aracının ikinci bölümünde ise asıl veri toplama aracı olan Tondeur ve diğerleri (2017) tarafından geliştirilen ve Alkan ve Emmioğlu Sarıkaya (2018) tarafından Türkçe' ye uyarlanan "Öğretmen Adayları için Bilgi ve İletişim Teknolojileri Yeterlikleri Ölçeği” yer almıştır. Ölçeğin Türk diline uyarlama çalışmasını yapan araştırmacılar ölçek geliştirme sürecini içeren çalışmalarında ölçeğin, uygun bir şekilde atıfta bulunularak kullanılmasının uygun olduğunu belirttiklerinden kullanım izni için yazarlarla ayrıca iletişime geçilmemiştir. Bilgi ve İletişim Teknolojileri Yeterlikleri Ölçeği "bilgi ve iletişim teknolojileri kullanımdesteği (BİT Kul. Des.)" ve "öğretim tasarımına yönelik bilgi ve iletişim teknolojileri (Öğr. Tas. BITT)" olmak üzere iki alt faktör ve 19 maddeden oluşmaktadır. Ölçek uyarlama çalı̧̧masında ölçeğin alt faktörlerinin iç tutarlılık katsayıları sırasıyla .91 ve .82 olarak hesaplanmıştır.Araştırmanın verileri analiz edilmeden önce araştırma kapsamında belirlenen örneklem grubundan elde edilen verilerin güvenilir olup olmadığını belirlemek adına iç tutarlılık katsayısı hesaplanmıştır. Verilerin iç tutarlılık katsayısı ölçeğin genelinde .85 olarak belirlenmiştir. Alt faktörlerde ise birinci alt faktörde .82, ikinci alt faktörde.76 olarak hesaplanmıştır. Büyüköztürk'e (2016) göre güvenirlik katsayısının .70 ve üzerinde olması test puanlarının güvenirliği için genel olarak yeterli görülmektedir. Ölçek öz bildirime dayalı olarak "kesinlikle katılmıorum=1 ve kesinlikle katılıyorum=5" şeklinde beşli Likert tipinde bir derecelendirmeye sahiptir. Ölçeğin tümünden alınacak maksimum puan 95 iken minimum puan ise 19'dur. Birinci alt faktörden alınacak maksimum puan 55 iken minimum puan 11, ikinci alt faktörde ise maksimum puan 40, minimum puan8'dir. Ölçeğin genelinde 1-35 puan düşük, 36-70 
puan orta ve 71-95 puan yüksek düzey bilgi ve iletişim teknolojileri yeterlikleri olarak belirlenmiştir. Bilgi ve iletişim teknolojileri kullanım desteği alt faktöründe 1-20 puan düşük, 2140 puan orta ve 41-55 puan yüksek düzey; öğretim tasarımına yönelik bilgi ve iletişim teknolojileri alt faktöründe 1-15 puan düşük, 16-30 puan orta ve 31-40 puan yüksek düzey bilgi ve iletişim teknolojileri yeterlikleri olarak kabul edilmiştir.

\section{Veri toplama süreci}

Veri toplama sürecinde öncelikle ilgili bölümlerde ders veren öğretim üyeleri ile görüşülmüş ve ölçek formlarının uygulanacağı ders saatleri belirlenmiştir. Ardından ilgili ders saatlerinde ölçek formu öğrencilere dağıtılmadan önce ölçeğin genel yapısı hakkında ve öğrencilerin ölçeği gönüllü olarak doldurmaları neticesinde kişisel bilgilerinin gizli kalacağına yönelik bilgi verilmiştir. Bu bilgilendirme neticesinde ölçek formunu doldurmak için gönüllü olan 335 öğretmen adayından veriler elde edilmiştir. Elde edilen 335 ölçek formundan eksik veya yanlış doldurulan 25 form araştırma kapsamından çıkarılmıştır. Sonuç olarak 310 öğretmen adayından elde edilen veriler analiz işlemine tabi tutulmuştur.

\section{Verilerin analizi}

Elde edilen verilerinin hangi istatistiksel analiz tekniği ile analiz edileceğini belirlemek adına parametrik istatistiksel tekniklere ilişkin varsayımları karşılama durumları incelenmiştir. $\mathrm{Bu}$ doğrultuda çarpıklık ve basıklık katsayıları, Q-Q Plot grafiği, histogram, Kolmogorov-Smirnov değerleri ve Kutu-çizgi grafiği incelenmiştir. Gerekli incelemeler sonucunda çarpıklık ve basıklık katsayı değerlerininSkewness-.032 ve Kurtosis-.064 olduğu; Kolmogorov-Smirnov değerlerinin .100 olduğu belirlenmiştir. Büyüköztürk'e (2016) göre çarpıklık ve basıklık katsayısı aralığının 1 ile +1 arasında yer alması ve Kolmogrov-Smirnov değerlerinin .05 'ten yüksek olması verilerin dağılımın normal olduğunu göstermektedir. Benzer şekilde incelenen Q-Q Plot grafiği, histogram ve Kutu-çizgi grafiğininde normal dağılımı işaret ettiği tespit edilmiştir. Bu doğrultulda verilerin analizinde parametrik istatistiksel tekniklerin kullanılmasına karar verilmiştir. Buradan hareketle öğretmen adaylarının bilgi ve iletişim teknolojilerine ilişkin yeterlik düzeylerini belirlemek amaciyla frekans, yüzde, aritmetik ortalama ve standart sapma gibi betimsel istatistiksel yöntemler kullanılmıştır. Bölüm, cinsiyet, kendine ait bilgisayara sahip olma ve bilgi ve iletişim teknolojilerine yönelik seminer veya kursa katılma durumu bağımsız değişkenlerinin analizinde gruplararası karşılaştırmalar için t-testi; sınıf düzeyi bağımsız değişkeni için ise tek yönlü varyans analizi (ANOVA) kullanılmıştır. Tüm analiz işlemleri için istatistiksel veri analizi paket programı kullanılmıştır. Anlamlılık düzeyi ise .05 olarak kabul edilmiştir.

\section{Etik}

Araştırmanın planlanmasından raporlaştırılmasına kadar yürütülen süreçlerin tamamında araştırma ve yayın etiği kurallarına uyulmuştur. Bu amaçla araştırmanın etik ilkelere uygun olduğunu gösteren etik kurul raporu Ondokuz Mayıs Üniversitesi Sosyal ve Beşerî Bilimler Etik Kurulu'ndan alınmıştır (25.10.2019/ Sayı No: 2019-326).

\section{Bulgular}

$\mathrm{Bu}$ bölümde öğretmen adaylarının bilgi ve iletişim teknolojileri yeterlikleri ölçeğine verdiklericevaplar neticesinde elde edilen bulgulara yer verilmiştir. Bu kapsamda öncelikle öğretmen adaylarının bilgi ve iletişim teknolojilerine yönelik yeterlikleri ele alınmıştır. Ardındanöğretmen adaylarının bilgi ve iletişim teknolojileriyeterlikleri; bölüm, cinsiyet, sınıf düzeyi, kendine ait bilgisayara sahip olma ve bilgi ve iletişim teknolojilerine yönelik seminer veya kursa katılma durumu değişkenlerinegöre farklılaşıp farklılaşmadığına ilişkin bulgular sunulmuştur.

\section{Öğretmen adaylarının bilgi ve iletişim teknolojileri yeterlik düzeyleri}

Öğretmen adaylarının bilgi ve iletişim teknolojileriyeterlik ölçeğinden aldıkları puanların genel dağılımı Tablo 2'de sunulmuştur. 
Tablo 2.

Öğretmen Adaylarının Bilgi ve İletişim Teknolojileri Yeterlikleri Ölçeğinden Elde Ettikleri Puanların Genel Dağılımı

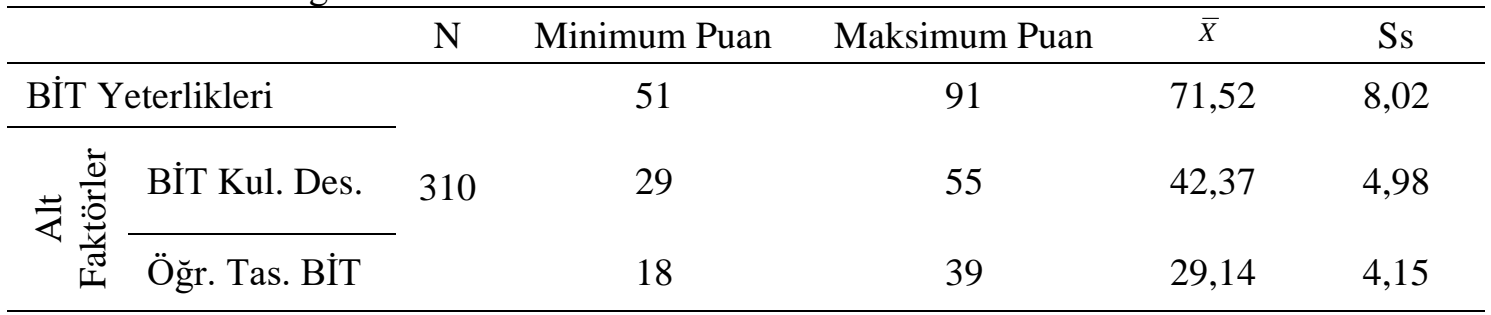

Tablo 2 incelendiğinde, öğretmen adaylarının toplam ölçek genelinde ve bilgi ve iletişim teknolojileri kullanım desteği alt faktöründe "yüksek düzeyde" bilgi ve iletişim teknolojileri yeterliklerine, öğretim tasarımına yönelikbilgi ve iletişim teknolojileri alt faktöründe ise "orta düzey" yeterliğe sahip olduğu bulunmuştur.

\section{Öğretmen adaylarının bilgi ve iletişim teknolojileriyeterliklerinin değişkenler açısından incelenmesi}

$\mathrm{Bu}$ bölümde öğretmen adaylarının bilgi ve iletişim teknolojileri yeterliklerini etkileyeceği düşünülen bölüm, cinsiyet, sınıf düzeyi, kendine ait bilgisayar sahip olma durumu ve bilgi ve iletişim teknolojilerine yönelik seminer ve kursa katılma durumu bağımsız değişkenlerine ilişkin bulgular ele alınmıştır.

\section{Bölüm}

Öğretmen adaylarının bilgi ve iletişim teknolojileriyeterlik düzeyleri arasında bölümlere göre anlamlı bir farklılığın olup olmadığını belirlemek için gerçekleştirilen ilişkisiz örneklemler t-testi sonuçları Tablo 3'te sunulmuştur.

Tablo 3.

Bilgi ve İletişim Teknolojileri Yeterlikleri Ölçeğinden Elde Edilen Puanların Bölümlere Göre ttesti Sonuçları

\begin{tabular}{|c|c|c|c|c|c|c|c|c|}
\hline & & Gruplar & $\mathrm{N}$ & $\bar{X}$ & Ss & SD & $\mathrm{t}$ & $\mathrm{p}$ \\
\hline \multirow{3}{*}{\multicolumn{2}{|c|}{ BİT Yeterlikleri }} & Sınıf Öğretmenliğ & 170 & 72,0 & 7,9 & \multirow{3}{*}{308} & \multirow{3}{*}{$\begin{array}{c}1,17 \\
5\end{array}$} & \multirow{3}{*}{,353 } \\
\hline & & & & 1 & 1 & & & \\
\hline & & $\begin{array}{l}\text { Sosyal Bilgiler } \\
\text { Öğretmenliği }\end{array}$ & 140 & $\begin{array}{c}70,9 \\
3\end{array}$ & $\begin{array}{c}8,1 \\
5\end{array}$ & & & \\
\hline \multirow{6}{*}{ 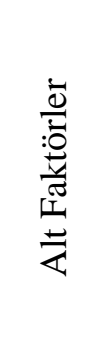 } & \multirow{3}{*}{$\begin{array}{l}\text { BİT Kul. } \\
\text { Des. }\end{array}$} & SınıfÖŏretmenliŏi & 170 & 42,4 & 4.7 & \multirow{3}{*}{308} & \multirow{3}{*}{,385 } & \multirow{3}{*}{ 177 } \\
\hline & & 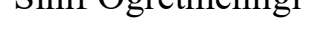 & 170 & 7 & 5 & & & \\
\hline & & $\begin{array}{l}\text { Sosyal Bilgiler } \\
\text { Öğretmenliği }\end{array}$ & 140 & $\begin{array}{c}42,2 \\
5\end{array}$ & $\begin{array}{c}5,2 \\
7\end{array}$ & & & \\
\hline & \multirow{3}{*}{$\begin{array}{l}\text { Öğr. Tas. } \\
\text { BİT }\end{array}$} & Sunıf Öŏretmenliŏj & & 29,5 & 4,0 & \multirow{3}{*}{308} & \multirow{3}{*}{$\begin{array}{c}1,81 \\
3\end{array}$} & \multirow{3}{*}{,369 } \\
\hline & & Sinit Ugretmening1 & $1 / 0$ & 3 & 5 & & & \\
\hline & & $\begin{array}{l}\text { Sosyal Bilgiler } \\
\text { Öğretmenliği }\end{array}$ & 140 & $\begin{array}{c}28.6 \\
7\end{array}$ & $\begin{array}{c}4.2 \\
4\end{array}$ & & & \\
\hline
\end{tabular}

Tablo 3'teki analiz sonuçları incelendiğinde öğretmen adaylarının bilgi ve iletişim teknolojileri yeterliklerininbölüm değişkenine göre farklılaşmadığ bulunmuştur $\left[\mathrm{t}_{(1,175)}=, 353, \mathrm{p}\right.$ > .05]. Alt faktörler açısından incelendiğinde de öğretmen adaylarının bilgi ve iletişim teknolojileri kullanım desteği ve öğretim tasarımına yönelik bilgi ve iletişim teknolojileri yeterliklerinin bölüm değişkenine göre istatistiksel olarak anlamlı bir sonuç ortaya çıkarmadığı belirlenmiştir 
$\left[\mathrm{t}_{(, 385)}=, 177, \mathrm{p}>.05 ; \mathrm{t}_{(1,1813)}=, 369, \mathrm{p}>.05\right]$. Bu doğrultuda sinıf ve sosyal bilgiler öğretmen adaylarının benzer bilgi ve iletişim teknolojileri yeterliklerine sahip oldukları söylenebilir.

\section{Cinsiyet}

Öğretmen adaylarının bilgi ve iletişim teknolojileriyeterlik düzeyleri arasında cinsiyete göre anlamlı bir farklılığın olup olmadığını tespit etmek amacıyla gerçekleştirilen ilişkisiz örneklemler t-testi sonuçları Tablo 4 'te sunulmuştur.

Tablo 4.

Bilgi ve İletişim Teknolojileri Yeterlikleri Ölçeğinden Elde Edilen Puanların Cinsiyete Göre ttesti Sonuçları

\begin{tabular}{|c|c|c|c|c|c|c|c|}
\hline & Gruplar & $\mathrm{N}$ & $\bar{X}$ & Ss & SD & $\mathrm{t}$ & p \\
\hline \multirow{2}{*}{ BİT Yeterlikleri } & Kadın & 230 & 71,41 & 7,78 & \multirow{2}{*}{308} & \multirow{2}{*}{,- 403} & \multirow{2}{*}{,319 } \\
\hline & Erkek & 80 & 71,83 & 8,72 & & & \\
\hline \multirow{4}{*}{ 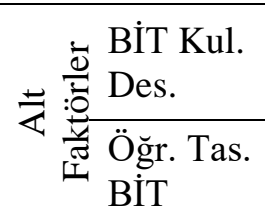 } & Kadın & 230 & 42,32 & 4.68 & \multirow{2}{*}{308} & \multirow{2}{*}{,- 307} & \multirow{2}{*}{, 041} \\
\hline & Erkek & 80 & 42,52 & 5,79 & & & \\
\hline & Kadın & 230 & 29,09 & 4,16 & \multirow{2}{*}{308} & \multirow{2}{*}{,- 409} & \multirow{2}{*}{, 811} \\
\hline & Erkek & 80 & 29,31 & 4.15 & & & \\
\hline
\end{tabular}

Tablo 4'teki analiz sonuçlarına bakıldığında ölçeğin toplamında erkek öğretmen adayları ile kadın öğretmen adayları arasında bilgi ve iletişim teknolojileri yeterlikleri açısından istatistiksel olarak anlamlı bir farklılığa rastlanmamıştır $\left[\mathrm{t}_{(308)}=-, 403, \mathrm{p}>.05\right]$. Alt faktörler açısından incelendiğinde ise öğretmen adaylarının bilgi ve iletişim teknolojilerikullanım desteği puanları arasında erkek öğretmen adayları lehine istatistiksel açıdan anlamlı farklılık olduğu görülmektedir $\left[\mathrm{t}_{(308)}=-, 307, \mathrm{p}<.05\right]$. Bu bulgudan yola çıkarak erkek öğretmen adaylarının bilgi ve iletişim teknolojilerikullanımı konusunda öğrencileri eğitmeye dönük olarak kendilerini daha yeterli gördükleri söylenebilir. Öğretim tasarımna yönelikbilgi ve iletişim teknolojilerialt faktörü incelendiğinde ise erkek ve kadın öğretmen adaylarının bilgi ve iletişim teknolojileri yeterlikleri arasında istatistiksel olarak anlamlı bir farklılık olmadığ belirlenmiştir $\left[\mathrm{t}_{(308)}=-, 409, \mathrm{p}>.05\right]$.

\section{Sinıf düzeyi}

Öğretmen adaylarının bilgi ve iletişim teknolojileriyeterlikleri ölçeğinden aldıkları puanların sınıf düzeylerine göre genel dağılımı Tablo 5 'te gösterilmektedir.

Tablo 5.

Bilgi ve İletişim Teknolojileri Yeterlikleri Ölçeğinden Elde Edilen Puanların Sınıf Düzeylerine Göre Dağılımı

\begin{tabular}{|c|c|c|c|c|c|}
\hline & & Gruplar & $\mathrm{N}$ & $\bar{X}$ & Ss \\
\hline & & 1.Sinif & 75 & 68,70 & 9,12 \\
\hline & & 2.Sinıf & 74 & 71,45 & 8,12 \\
\hline BİT & terlikleri & 3.Sinif & 82 & 71,57 & 6,97 \\
\hline & & 4.Sinif & 79 & 71,21 & 7,0 \\
\hline & & Toplam & 310 & 71,52 & 8,02 \\
\hline & & 1.Sinif & 75 & 40,65 & 5,94 \\
\hline & & 2.Sinif & 74 & 41,93 & 4,72 \\
\hline 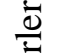 & BİT Kul. Des. & 3.Sinıf & 82 & 42,62 & 4,31 \\
\hline : & & 4.Sinıf & 79 & 44,17 & 4,29 \\
\hline 旄 & & Toplam & 310 & 42,37 & 4,98 \\
\hline 푼 & & 1.Sinif & 75 & 28,05 & 4,61 \\
\hline & Öğr. Tas. BİT & 2.Sinif & 74 & 29,52 & 4,29 \\
\hline & & 3.Sinif & 82 & 28,95 & 3,73 \\
\hline
\end{tabular}




\begin{tabular}{lcccc}
\hline 4.Sinif & 79 & 30,03 & 3,78 \\
Toplam & 310 & 29,14 & 4,15 \\
\hline
\end{tabular}

Tablo 5'teki analiz sonuçları öğretmen adaylarının sınıf düzeyi arttıkça bilgi ve iletişim teknolojileriyeterlik puanlarının da arttığını göstermektedir. Alt faktörler açısından incelendiğinde bilgi ve iletişim teknolojilerikullanım desteği ve öğretim tasarımına yönelikbilgi ve iletişim teknolojilerifaktörlerinde yine sınıf düzeyine paralel bir şekilde puanların arttığ görülmektedir. Gruplar arasındaki bu farkların anlamlı olup olmadığını belirlemek amacıyla tek yönlü varyans analizi (ANOVA) yapılmış ve analiz sonuçları Tablo 6'da verilmiştir.

Tablo 6.

Bilgi ve İletişim Teknolojileri Yeterlikleri Puanlarının Sınıf Düzeyine Göre Tek Yönlü Varyans Analizi Sonuçları

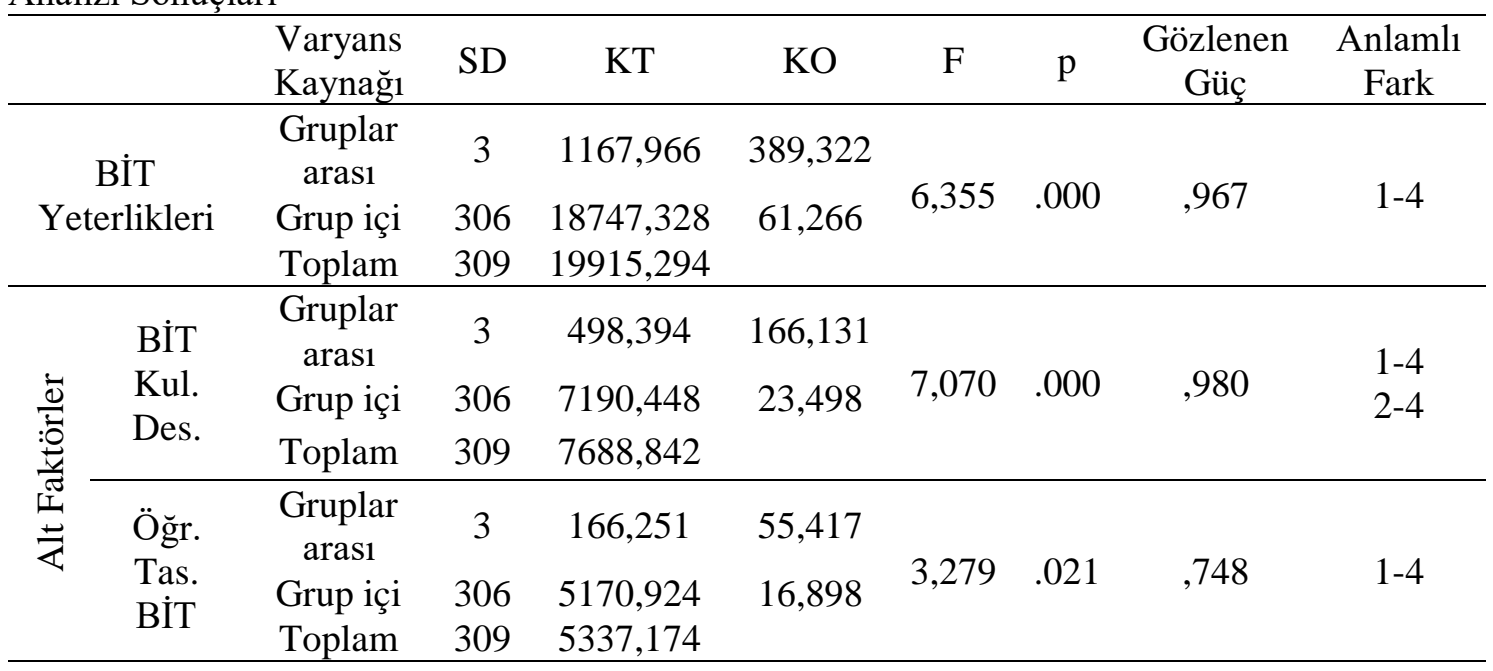

Tablo 6'daki analiz sonuçları incelendiğinde öğretmen adaylarının bilgi ve iletişim teknolojileriyeterlikleri puanları arasında sınıf düzeylerine göre istatistiksel açıdan anlamlı bir farklılık olduğu belirlenmiştir $\left[\mathrm{F}_{(3,306)}=6,355\right.$. $\left.\mathrm{p}<.05\right]$. Başka bir deyişle öğretmen adaylarının bilgi ve iletişim teknolojileriyeterlik düzeyleri sınıf düzeyine göre değişmektedir. Ortaya çıkan farklılığın hangi gruplar arasında olduğunu belirlemek için yapılan Tukey testi sonuçları, 1. sinıflar $(\bar{x}=68.70)$ ile 4. sinıfların $(\bar{x}=71.21)$ bilgi ve iletişim teknolojileriyeterlik puanları arasında 4. sinıflar lehine anlamlı bir fark olduğunu göstermektedir. Bu bulguya dayalı olarak 4. sinıfların 1. sinıflara kıyasla daha fazla bilgi ve iletișim teknolojileriyeterliğine sahip olduğu söylenebilir.

Ölçeğin alt faktörlerine dair puanlar ele alındığında bilgi ve iletişim teknolojileri kullanım desteği ve öğretim tasarımına yönelikbilgi ve iletişim teknolojileri alt faktörlerinde istatistiksel açıdan anlamlı bir fark oluştuğu $(\mathrm{p}<.05)$ görülmüştür. Buna göre öğretmen adaylarının bilgi ve iletişim teknolojileri kullanım desteği puanları açısından 1. sinıflar $(\overline{\mathrm{x}}=40.65)$ ve 4 . sınıflar $(\overline{\mathrm{x}}=44,17)$ arasinda 4. siniflar lehine, 2. siniflar $(\overline{\mathrm{x}}=41,93)$ ile 4. siniflarin $(\overline{\mathrm{x}}=44,17)$ puanlar1 arasında 4. sınıflar lehine istatistiksel açıdan anlamlı bir fark olduğu belirlenmiştir. Benzer şekilde öğretim tasarımına yönelikbilgi ve iletişim teknolojilerialt faktöründe 1 . sinıflar $(\bar{x}=28,05)$ ve 4 . sinıflar $(\overline{\mathrm{x}}=30,03)$ arasında 4 . sinıflar lehine anlamlı farklılık olduğu tespit edilmiştir. Bu bulgulara dayalı olarak 4. sınıfta öğrenim gören öğretmen adaylarının alt sınıflarda öğrenim gören öğretmen adaylarına göre bilgi ve iletişim teknolojileri kullanımdesteği ve öğretim tasarımına yönelikbilgi ve iletişim teknolojileri yeterlikleri açısından kendilerini daha yeterli algıladıkları söylenebilir.

\section{Kendine ait bilgisayara sahip olma durumu}

Öğretmen adaylarının bilgi ve iletişim teknolojileriyeterlik düzeyleri açısındankendine ait bilgisayara sahip olma durumuna göre anlamlı bir farklılığın olup olmadığını belirlemek için yapılan ilişkisiz örneklemler t-testi sonuçları Tablo 7'de sunulmuştur. 
Tablo 7.

Bilgi ve İletişim Teknolojileri Yeterlikleri Ölçeğinden Elde Edilen Puanların Kendine Ait Bilgisayara Sahip Olma Durumuna Göre t-testi Sonuçları

\begin{tabular}{|c|c|c|c|c|c|c|c|}
\hline & Gruplar & $\mathrm{N}$ & $\bar{X}$ & Ss & SD & $\mathrm{t}$ & $\mathrm{p}$ \\
\hline \multirow{2}{*}{ BİT Yeterlikleri } & Evet & 182 & 71,79 & 8,17 & \multirow{2}{*}{308} & \multirow{2}{*}{,693 } & \multirow{2}{*}{ 319 } \\
\hline & Hayır & 128 & 71,14 & 7,83 & & & \\
\hline \multirow{4}{*}{ 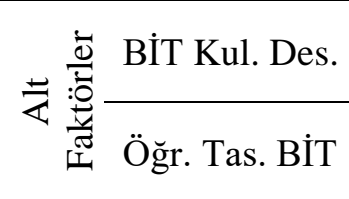 } & Evet & 182 & 42,57 & 5,12 & \multirow{2}{*}{308} & \multirow{2}{*}{,816 } & \multirow{2}{*}{,473 } \\
\hline & Hayır & 128 & 42,10 & 4,79 & & & \\
\hline & Evet & 182 & 29,21 & 4,27 & \multirow{2}{*}{308} & \multirow{2}{*}{,- 360} & \multirow{2}{*}{ 270 } \\
\hline & Hayır & 128 & 29,04 & 3,99 & & & \\
\hline
\end{tabular}

Tablo 7'deki analiz sonuçlarına bakıldığında öğretmen adaylarının bilgi ve iletişim teknolojileri yeterliklerinin kendine ait bilgisayara sahip olma değişkenine göre anlamlı farklılığasahip olmadığ bulunmuştur $\left[\mathrm{t}_{(308)}=, 693, \mathrm{p}>\right.$.05]. Alt faktörler açısından incelendiğinde de öğretmen adaylarının bilgi ve iletişim teknolojilerikullanım desteği ve öğretim tasarımına yönelikbilgi ve iletişim teknolojileripuanları arasında da istatistiksel açıdan anlamlı farklılık

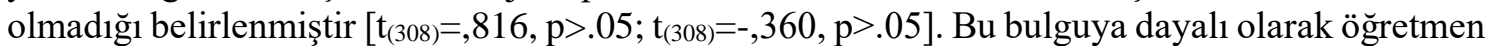
adaylarının kendine ait bilgisayara sahip olma durumlarının bilgi ve iletişim teknolojileri yeterliklerini etkilemediği söylenebilir.

\section{Bilgi ve iletişim teknolojilerine yönelik seminer veya kursa katılma durumu}

Öğretmen adaylarının bilgi ve iletişim teknolojileriyeterlik düzeyleri açısındanbilgi ve iletişim teknolojilerine yönelik seminer veya kursa katılma durumu değişkenine göre anlamlı bir farklıı̆̆ın olup olmadığını belirlemek amacıyla gerçekleştirilen ilişkisiz örneklemler t-testi sonuçları Tablo 8'de sunulmuştur.

Tablo 8.

Bilgi ve İletişim Teknolojileri Yeterlikleri Ölçeği'nden Elde Edilen Puanların Seminer veya Kursa Katılma Durumlarına Göre t-testi Sonuçları

\begin{tabular}{|c|c|c|c|c|c|c|c|}
\hline & Gruplar & $\mathrm{N}$ & $\bar{X}$ & Ss & SD & $\mathrm{t}$ & $p$ \\
\hline \multirow{2}{*}{ BİT Yeterlikleri } & Evet & 34 & 72,91 & 10,14 & \multirow[b]{2}{*}{308} & \multirow[b]{2}{*}{1,067} & \multirow[b]{2}{*}{,014 } \\
\hline & Hayır & 276 & 71,35 & 7,73 & & & \\
\hline \multirow{4}{*}{ 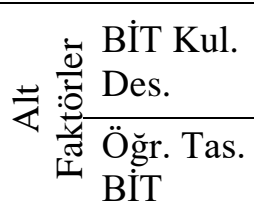 } & Evet & 34 & 43,26 & 6,27 & \multirow{2}{*}{308} & \multirow{2}{*}{1,100} & \multirow{2}{*}{,009 } \\
\hline & Hayır & 276 & 42,26 & 4,80 & & & \\
\hline & Evet & 34 & 29,64 & 4,50 & \multirow{2}{*}{308} & \multirow{2}{*}{,741 } & \multirow{2}{*}{, 445 } \\
\hline & Hayır & 276 & 29,08 & 4,50 & & & \\
\hline
\end{tabular}

Tablo 8'deki analiz sonuçlarına bakıldığında ölçeğin toplamında bilgi ve iletişim teknolojilerine yönelik seminerveya kursa katılan öğretmen adaylarının lehine anlamlı bir farklı1ık olduğu tespit edilmiştir $\left[\mathrm{t}_{(308)}=1,067, \mathrm{p}<.05\right]$. Alt faktörleraçısından incelendiğinde debilgi ve iletişim teknolojilerine yönelik ders alan öğretmen adaylarının bilgi ve iletişim teknolojileri. Kullanım desteğipuanları arasında seminer veya kursa katılmayan öğretmen adaylarına göre katılan öğretmen adayları lehine istatistiksel açıdan anlamlı farklılık olduğu görülmektedir $\left[\mathrm{t}_{(308)}=1,100, \mathrm{p}<.05\right]$. Bu bulgudan yola çıkarak seminer veya kursa katılan öğretmen adaylarının bilgi ve iletişim teknolojilerikullanımı konusunda öğrencileri eğitmeye dönük olarak kendilerini daha yeterli gördükleri söylenebilir. Öğretimtasarımına yönelikbilgi ve iletişim teknolojilerialt faktörüincelendiğinde ise istatistiksel açıdan anlamlı bir farklılığa rastlanmamıştır $\left[\mathrm{t}_{(308)}=, 741, \mathrm{p}>.05\right]$.

\section{Tartışma, Sonuç ve Öneriler}


Bilgi ve iletişim teknolojileriyeterliklerinin incelendiği bu araştırmada; öğretmen adaylarının toplam ölçek genelinde "yüksek düzeyde", bilgi ve iletişim teknolojilerikullanım dersteği alt faktöründe "yüksek düzeyde", öğretim tasarımına yönelikbilgi ve iletişim teknolojilerialt faktöründe ise "orta düzeyde" yeterliğe sahip oldukları bulunmuştur. Öğretmenlerin; teknoloji okuryazarı olma, bilgisayar ve iletişim teknolojileri alanındaki gelişmeleri takip edebilme, derslerde teknolojiyi kullanabilme, ders planlarında bilgisayar ve iletişim teknolojilerine yer verebilme, öğrencileri teknoloji kullanmaya teşvik edebilme ve bu amaçla öğretim ortamını düzenleyebilme becerilerine sahip olmaları gerektiği (International Society for Technology in Education, 2020; Milli Eğitim Bakanlığı, 2017; Yükseköğretim Kurulu, 2018) göz önüne alındığında bu araştırmanın bir sonucu olarak öğretmen adaylarının bilgi ve iletişim teknolojileriyeterliklerinin yüksek düzeyde bulunmasının eğitim sistemi için olumlu bir durum olduğu söylenebilir. Alanyazın incelendiğinde araştırmanın bulgularını deskteleyen bazı sonuçlara ulaşılmıştır. Örneğin Heerwegh, De Wit ve Verhoeven (2016) ve Ormanc1 (2019) öğretmen adaylarının bilgi ve iletişim teknolojileribecerilerinin yüksek düzeyde olduğunu; Ozan ve Taşgın (2017) öğretmen adaylarının eğitim teknolojisi standartlarına yönelik öz yeterliklerinin yüksek olduğunu tespit etmişlerdir. Ayrıca bazı araştırmalarda öğretmen adaylarının yüksek düzeyde bilgi okuryazarı olduğu (Özdemir, Akbaş ve Çakır, 2010), öğretim faaliyetlerinde teknoloji kullanımına yönelik tutumlarının yüksek olduğu (Ünal Bozcan, 2010), eğitimde bilgi ve iletişim teknolojilerikullanımı (Şad ve Nalçac1, 2015)ve teknopedagojik yeterlikler (Yurdakul, 2011) açısından kendilerini yeterli gördükleri belirlenmiştir. Öğretmen adaylarının bilgi ve iletişim teknolojileriyeterliklerinin yüksek düzeyde olmasının bilgi çağının gereklerini yerine getirebilme başarısı ve bilgi ve iletişim teknolojilerikullanımının yaygınlaşması açısından önemli bir sonuç olduğu ifade edilebilir. Geçen zaman içerisinde teknolojinin hızla gelişmesi, hayatın her alanında kullanılıyor olması ve öğretmen adaylarının bu teknolojik gelişmelerin içerisine doğarak, küçük yaşlardan itibaren teknolojik araçlarla etkileşimlerinin fazla olmasıbilgi ve iletişim teknolojileri yeterliklerinin yüksek düzeyde olmasını açıklayıcı etkenlerdir. Bu çalışmaların yanı sıra öğretmen adaylarının bilgi ve iletişim teknolojileri yeterliklerinin orta düzeyde olduğunu gösteren araştırma bulgularına (Saygıner, 2016) da rastlanılmaktadır. Bu farklılığın Saygıner'in (2016) araştırmasındaki örneklem grubunun farklı branşlara ve özelliklere sahip öğretmen adaylarından oluşmasından kaynaklandığı düşünülmektedir.

Öğretmen adaylarının bilgi ve iletişim teknolojileri yeterliklerinin bölüm değişkenine göre istatistiksel açıdan farklılaşmadığı tespit edilmiştir. Bu sonuca paralel şekilde Usta ve Korkmaz (2010) ve Saygıner'in (2016) araştırmalarında da sınıf ve sosyal bilgiler öğretmeni adaylarının bilgisayar yeterlik düzeylerinin branşa göre farklılaşmadığı görülmektedir. Öğretmen adaylarının bölümleri açısından bilgi ve iletişim teknolojileri yeterliklerinin, bilgi ve iletişim teknolojileri kullanımının ve dijital teknolojiler konusundaki yeterlik algılarının farklılaştığını gösteren araştırmalarda baskın olarak bilgisayar ve öğretim teknolojileri branşının diğer branşlara göre anlamlı düzeyde yüksek beceri ve yeterlik göstergelerine sahip olduğu; diğer branşlar arasında ise dikkat çekici bir farklılı̆̆ın göze çarpmadığı görülmektedir (Akbulut, Odabaşı ve Kuzu, 2011; Aytaş, 2020; Şad ve Nalçac1, 2015).

Öğretmen adaylarının bilgi ve iletişim teknolojileriyeterliklerinintoplam ölçek genelindecinsiyete göre farklılaşmadığı tespit edilmiştir. Bilgi ve iletişim teknolojileri kullanım desteği alt faktöründe ise erkekler lehine anlamlı farklılığa rastlanmıştır. Bu sonuç doğrultusunda; erkek öğretmen adaylarının bilgi ve iletişim teknolojilerikullanım desteği konusunda daha yeterli oldukları söylenebilir. Alanyazındaki öğretmen adaylarıyla yürütülen araştırmalarda bu sonuçlara paralel olarak erkeklerin; bilgi ve iletişim teknolojileribecerileri (Heerwegh, De Wit ve Verhoeven, 2016; Ormanc1, 2019) ve bilgisayar yeterliklerinin (Saygıner, 2016; Y1lmaz, Üredi ve Akbaşlı, 2015)daha yüksek olduğu sonuçlarına ulaşıldığ görülmektedir. Bu sonuçlar göz önüne alındığında araştırmalarda tespit edilen cinsiyet farklılığının biyolojik bir durumdan çok bilgi ve iletişim teknolojisi ile etkileşim ve teknolojik araçlarla olan deneyimle ilgili olduğu söylenebilir. Erkeklerin teknolojik araçlara daha fazla ilgi duyması ve bu araçlarla daha fazla zaman geçirmelerinden dolayı bu farklılığın ortaya çıktığ ifade edilebilir (He ve Freeman, 2010). Nitekim cinsiyetin öğretmen adaylarının bilgi ve iletişim teknolojileri kullanım yeterliklerini, 
yeterlik algılarını, becerilerini ve eğitim teknolojisi standartlarına yönelik öz yeterliklerini etkileyen bir faktör olmadığını ortaya koyan araştırmalar da mevcuttur(Aytaş, 2020; Şad ve Nalçac1, 2015).

Öğretmen adaylarının bilgi ve iletişim teknolojileriyeterliklerinin sınıf düzeyi artıkça toplam ölçek puanlarında ve alt faktörlerinde paralel bir şekilde artığı bulunmuştur. Ölçek toplam puanı ve her iki alt faktörde 1. ve 4. sınıflar arasında 4. sınıflar lehine; bilgi ve iletişim teknolojileri kullanım desteği alt faktöründe de 2. ve 4. sınıflar arasında 4. Sinıflar lehine anlamlı farklılığın oluştuğu tespit edilmiştir. Buradan hareketle 4. sınıfların, 1. sınıf ve 2. sınıflara göre bilgi ve iletişim teknolojilerikonusunda daha yeterli oldukları söylenebilir. Bu sonuçların alanyazındaki bazı araştırma sonuçlarıyla örtüştüğü görülmektedir. Örneğin; Ormancı (2019) tarafından yürütülen araştırmada sınıf düzeyi arttıkça bilgisayar ve iletişim teknolojileri becerilerinin de $\operatorname{arttığı~belirtilmektedir.~Bilgi~ve~iletişim~teknolojileriyeterliklerinin~sınıf~düzeyi~ile~paralel~bir~}$ şekilde artması ögretmen adaylarının hizmet öncesi eğitim dönemlerinde yaşadıkları bilgi ve iletişim teknolojilerideneyimleri ile açıklanabilir. Bir başka ifadeyle öğretmen adayları hizmet öncesi eğitim sürecinin başından sonuna doğru sınıf düzeyi arttıkça bilgi ve iletişim teknolojileriile ilgili daha fazla ders almakta ya da aldıkları derslerde bilgisayar ve iletişim teknolojilerini daha fazla kullanma deneyimi yaşamaktadırlar. Aytaş'ın (2020) araştırmasında ise öğretmen adaylarının bilgi ve iletişim teknolojileri becerileri üzerinde sınıf düzeyinin etkili olmadığı ifade edilmiş ve bu durum öğretmen adaylarının yaşlarının birbirine yakın olması nedeniyle teknolojiye ilişkin deneyimlerinin benzer olduğu ile açıklanmıştır.

Kendine ait bilgisayara sahip olma durumun öğretmen adaylarının bilgi ve iletişim teknolojileri yeterliklerini etkilemediği tespit edilmiştir. Bilgisayar sahibi olma değişkeni öğretmen adaylarınınbilgi ve iletişim teknolojilerikullanmalarını ve bu konudaki deneyimlerini ifade etmektedir. Dolayısıyla öğretmen adaylarının bilgi ve iletişim teknolojilerideneyimlerinin miktarı ile bilgi ve iletişim teknolojileriyeterlikleri arasında bir ilişkinin bulunmadığı ifade edilebilir. Şad ve Nalçacı'nın (2015) araştırmalarında bilgi ve iletişim teknolojileri yeterliklerinin kendine ait bilgisayara sahip olma durumuna göre farklılaşmadığ 1 görülmektedir. Bu durum bilgi ve iletişim teknolojilerinin hayatın bir parçası olduğu gerçeğiyle açıklanabilir. Bilgi ve iletişim teknolojilerivar olan durumda hayatın her alanında ve süreklilik içerisinde kullanıldığı için öğretmen adaylarının bilgi ve iletişim teknolojileriyeterliklerinin doğal olarak yüksek düzeyde bulunduğu ve deneyim miktarının, bilgi ve iletişim teknolojileriyeterliğini anlamlı derecede etkilemediği şeklinde yorumlanabilir. Nitekim teknolojinin günlük yaşamın her alanına bu denli etki etmediği, geçmiş yıllarda gerçekleştirilen araştırma sonuçları incelendiğinde bilgi ve iletişim teknolojileri deneyimlerinin bilgi ve iletişim teknolojileri becerilerini etkilediği ve bilgi ve iletişim teknolojileri ile daha fazla deneyim yaşayan bireylerin bu alandaki beceri düzeylerinin de daha yüksek olduğu (Haznedar, 2012) görülmektedir. Benzer şekilde bazı araştırmalarda evinde bilgisayar ve internet bulunan öğretmen adaylarının bilgisayar yeterliklerinin (Saygıner, 2016), bilgi ve iletişim teknolojileri becerilerinin (Aytaş, 2020) ve eğitimde teknoloji kullanımlarının daha yüksek olduğu görülmektedir (Yılmaz, Üredi ve Akbaşlı, 2015).

Bilgi ve iletişim teknolojilerine yönelik seminer veya kursa katılan öğretmen adaylarının bilgi ve iletişim teknolojileri yeterliklerinin toplam ölçek genelinde ve bilgi ve iletişim teknolojileri kullanım desteği alt faktöründe anlamlı derecede yüksek olduğu; öğretimtasarımına yönelikbilgi ve iletişim teknolojilerialt faktöründeise seminer veya kursa katılma durumunun anlamlı bir sonuç ortaya çıkarmadığı tespit edilmiş̧ir. Koçak Usluel, Kuşkaya Mumcu ve Demiraslan'ın (2007) araştırmalarında; bilgi ve iletişim teknolojilerinin derslerde kullanımı ile ilgili eğitim alan öğretmenlerin bu konuda hiç eğitim almayan öğretmenlere göre bilgi ve iletişim teknolojileriniöğrenme öğretme ortamında daha fazla kullandıkları görülmektedir. Bilgi ve iletişim teknolojileri ile ilgili ders alan öğretmenlerin aldıkları eğitim hizmet öncesi ve hizmet içi olarak ayrıca incelendiğinde hizmet öncesi eğitim alan öğretmenlerin hizmet içi eğitim alan öğretmenlere göre öğretim etkinliklerinde daha fazla bilgi ve iletişim teknolojilerikullandıkları tespit edilmiştir. Hizmet öncesi ve hizmet içi eğitim etkinliklerinin ikisine birden katılan öğretmenlerin ise bilgi ve iletişim teknolojilerini öğretim sürecine daha başarılı entegre edebildikleri görülmektedir. Ayrıca araştırma sonuçları (Bell, Waeng ve Binns, 2013; Koh, 2011) 
bilgi ve iletişim teknolojilerini geliştirmeye yönelik gerçekleştirilen eğitimlerin, öğretmen adaylarının öğretim ortamlarında teknoloji kullanımına yönelik öz yeterlik algılarını olumlu etkilediği ve teknolojiyi derse entegre edebilme becerilerini geliştirdiğini göstermektedir. Altun'un (2007) çalı̧̧masında ise öğretmenlerin bilgisayar kullanma becerileri hizmet içi eğitim etkinliklerine katılıp katılmama durumuna göre anlamlı bir farklılık yaratmazken hizmet öncesi dönemde bilgisayar eğitimi alan öğretmenlerin bilgisayar kullanma becerilerinin daha yüksek düzeyde olduğu sonucu elde edilmiştir. Dolayısıyla bilgi ve iletişim teknolojilerialanındaki çalışmaların bütünsel olarak hizmet öncesi ve hizmet içi eğitim süreçlerinde önemli rol oynadığ 1 ve özellikle hizmet öncesi sürecin gerekli bilgi ve becerilerin kazandırılmasında kritik öneme sahip olduğu söylenebilir. Ayrıca 2020 yılının başlarında ortaya çıkan ve tüm dünyayı olumsuz etkileyen Covid-19 salgını neticesinde birçok ülkede olduğu gibi Türkiye'de de örgün eğitim kurumlarının eğitim öğretim etkinliklerini uzaktan eğitim ile sürdürmeye çalışması, bilgi ve iletişim teknolojileri yeterliklerinin önemini gün yüzüne çıkarmaktadır. Uzaktan eğitim süreçlerinin nitelikli ve verimli olabilmesi bu süreci etkili yönetebilen eğitim sistemlerine ve sistemin en önemli ögesi olan öğretmenlerin bilgi ve iletişim teknolojileri yeterlik düzeylerinin yüksek olmasına bağlıdır. Bilgi ve iletişim teknolojilerine yönelik bilgi ve beceriler açısından yeterli öğretmenlerin yetiştirilmesi ise hizmet öncesi dönemin rolünü ve önemini bu süreçte bir kez daha hissettirmektedir.

$\mathrm{Bu}$ araştırmanın sonuçlarından yola çıkarak birtakım öneriler getirilmiştir. Bilgi ve iletişim teknolojilerinin eğitim süreçleri ile ilişkisini mercek altına alan nitel çalışmaların yapılması ve özellikle öğretmenlerin bilgi ve iletişim teknolojileri deneyimlerini konu alan eylem araştırmalarının geçekleştirilmesi önerilebilir. Çalışma sonuçlarından yola çıkarak; lisans düzeyinde öğrencilerin bilgi ve iletişim teknolojileriyeterliklerinin artırılmasına yönelik eğitsel planlamaların yapılması, öğretim programlarına konu alanı ile ilgili derslerin eklenmesi, var olan derslerin ders sürelerinin artırılması ve teorik süreçler ile birlikte uygulamalı eğitim süreçlerine ağırlık verilmesi önerilebilir. Öğretmen adaylarının bilgi ve iletişim teknolojileri yeterliklerini geliştirmeleri için örgün eğitim dışında eğitim etkinlerine katılmaları önerilebilir.

Öğretmen adaylarının bilgi ve iletişim teknolojileri yeterliklerinin incelendiği bu araştırmanın yalnızca bir üniversitede, belirli bir dönemde öğrenim gören öğretmen adayları ile yürütülmesi araştırmanın bir sınırlılığı olarak ortaya çıkmaktadır. Ayrıca araştırma, öğretmen adaylarının bilgi ve iletişim teknolojileri yeterliklerini belirlemek için kullanılan ölçekte yer alan bilgi ve iletişim teknolojileri kullanım desteği ve öğretim tasarımına yönelik bilgi ve iletişim teknolojileri alt faktörleri ile sınırlıdır. Son olarak, araştırma öğretmen adaylarına uygulanan ölçme aracından elde edilen verilerle ve verilerin istatiksel analizi ile sinırlıdır. Bu doğrultuda bilgi ve iletişim teknolojileri yeterliklerine yönelik ileride yapılacak olan araştırmaların farklı üniversitelerde ve çeşitli bölümlerde öğrenim gören öğretmen adaylarını kapsayacak biçimde daha geniş örneklem gruplarında, farklı yapılarda geliştirilen çeşitli ölçme araçları kullanılarak ve farklı istatistiksel analizlerle ele alınması önerilmektedir.

\section{Etik Kurul Onay Bilgileri}

Ondokuz Mayıs Üniversitesi Sosyal ve Beşerî Bilimler Etik Kurulu

Karar Tarihi: 25.10.2019

Toplantı Sayıs1: 9

Karar Say1s1: 2019/326

Karar No: 2019-326

\section{Kaynaklar}

Akbulut, Y., Odabaş1, H. ve Kuzu, A. (2011). Perceptions of preservice teachers regarding the integration of information and communication technologies in Turkish education faculties. Turkish Online Journal of Educational Technology, 10(3), 175-184. Erişim adresi: http://www.tojet.net/articles/v10i3/10320.pdf

Akkoyunlu, B. (1996). Bilgisayar okur yazarlığı yeterlilikleri ile mevcut ders programlarının kaynaştırılmasının öğrenci başarı ve tutumlarına etkisi. Hacettepe Üniversitesi Eğitim 
Fakültesi Dergisi, 12, 127-134. Erişim adresi: http://www.efdergi.hacettepe.edu.tr /yonetim/icerik /makaleler/1275-published.pdf

Alkan, M. F. ve Emmioğlu Sarıkaya, E. (2018). Öğretmen adayları için bilgi ve iletişim teknolojileri yeterlikleri ölçeğinin Türk kültürüne uyarlanmas1. Bartın Üniversitesi Eğitim Fakültesi Dergisi, 7(2), 665-691. http://dx.doi.org/10.14686/buefad.375745

Altun, S. (2007). Illköğretim okullarında çalışan ögretmenlerin bilgisayar kullanma becerileri ve bilgisayar destekli öğretime ilişkin tutumları üzerine bir araştırma: Bartın ili örneği (Yayınlanmamış yüksek lisans tezi). Gazi ÜniversitesiEğitim Bilimleri Enstitüsü, Ankara.

Atalay, N. ve Anagün, Ş. S. (2014). Kırsal alanlarda görev yapan sınıf öğretmenlerinin bilgi ve iletişim teknolojilerinin kullanımına ilişkin görüşleri. Eğitimde Nitel Araşstırmalar Dergisi, 2(3), 9-27. http://doi.org/10.14689/issn.2148-2624.1.2c3s1m

Avşar, P. (2011). Beden eğitimi öğretmenlerinin hizmetiçi eğitim programlarını değerlendirmesi. Milli Eğitim Dergisi, 191, 230-242. Erişim adresi: https://dergipark.org.tr/en/download/article-file/442548

Aypay, A. (2010). Information and communication technology usage and achivement of Turkish students in PISA 2006. The Turkish Online Journal of Educational Technology, 9(2), 116-124. Erişim adresi: https://files.eric.ed.gov/fulltext/EJ898009.pdf

Aytaş, Ö. (2020). Ögretmen adaylarının bilgi ve iletişim teknolojileri becerileri ile derste teknoloji kullanımına yönelik eğilimlerinin incelenmesi (Yayımlanmamış yüksek lisans tezi). Firat ÜniversitesiEğitim Bilimleri Enstitüsü, Elazı̆̆.

Ayvacı, H. Ş., Bakırcı, H. ve Yıldız, M. (2014). Fen bilimleri öğretmenlerinin hizmet içi eğitim uygulamalarına ilişkin görüşleri ve beklentileri. Amasya Üniversitesi Ĕ̆itim Fakültesi Dergisi, 3(2), 357-383. Erişim adresi: https://dergipark.org.tr/tr/pub/amauefd /issue/1731/21228

Bell, R. L., Waeng, J. L. ve Binns, I. C. (2013). Learning in context: Technology integration in a teacher preparation program informed by situated learning theory. Journal of Research in Science Teaching, 50(3), 348-379. https://doi.org/10.1002/tea.21075

Berkyürek, İ. (2008). Fen ve teknoloji ögretmenlerinin bilgi ve iletişsim teknolojilerini kullanımına yönelik bir inceleme Bolu Ili örneği (Yayımlanmamış yüksek lisans tezi). Abant İzzet Baysal Üniversitesi Sosyal Bilimler Enstitüsü, Bolu.

Birgin, O., Çoker, B. ve Çatlığlu, H. (2010). Investigation of first year pre-service teachers' computer and internet uses in terms of gender. Procedia Social and Behavioral Sciences, 2(2), 1588-1592. https://doi.org/10.1016/j.sbspro.2010.03.241

Boshuizen, H. P. A. ve Wopereis, I. G. J. H. (2003). Pedagogy of training in information and communications technology for teachers and beyond. Technology, Pedagogy and Education, 12(1), 149-159. Erişim adresi: https://www.semanticscholar.org/paper /Pedagogy-of-Training-in-Information-and-Technology-Boshuizen-Wopereis 151a365c40bf547cfcfccab389602bbd5ef388c3f

Büyüköztürk, Ş. (2016). Sosyal bilimler için veri analizi el kitabı: İstatistik, araştırma deseni SPSS uygulamalart ve yorum (22. Bask1). Ankara: Pegem Akademi.

Büyüköztürk, Ş., Çakmak, K. E., Akgün, Ö. E., Karadeniz, Ş. ve Demirel, F. (2015). Bilimsel araştırma yöntemleri (19. Bask1). Ankara: Pegem Akademi Yayıncılık.

Chou, C. M., Hsiao, C. H., Shen, H. C. ve Chen, S. G. (2010). Analysis of factors in technological and vocational school teachers' perceived organizational innovative climate and continuous use of e-teaching: Using computer self-efficacy as an intervening variable. The Turkish Online Journal of Educational Technology, 9(4), 35-48. Erişim adresi: https://eric.ed.gov/?id=EJ908070

Cüre, F. ve Özdener, N. (2008). Öğretmenlerin bilgi ve iletişim teknolojileri (Bilgi ve iletişim teknolojileri) uygulama başarıları ve bilgi ve iletişim teknolojilerine yönelik tutumları. Hacettepe Üniversitesi Eğitim Fakültesi Dergisi, 34, 41-53. Erişim adresi: https://arastirmax.com/en/publication/hacettepe-universitesi-egitim-fakultesi-dergisi /1/ogretmenlerin-bilgi-iletisim-teknolojileri-bilgi ve iletişim teknolojileri-uygulama- 
basarilari-bilgi ve iletişim teknolojilerie-yonelik-tutumlari/arid/f5881383-92e8-4409bbf4

Çobanoğlu, İ., Ateş, A., İliç, U. ve Yılmaz, E. (2009). Investigating prospective computer teachers' perceptions on e-learning. Procedia-Social and Behavioral Sciences, 1(1), 1460-1463. https://doi.org/10.1016/j.sbspro.2009.01.257

Çoklar, M. (2012). Genel ögretmen yeterlikleri içerisinde bilgi ve iletişim teknolojileri: Afyonkarahisar ili örneği (Yayımlanmamış yüksek lisans tezi). Necmettin Erbakan ÜniversitesiEğitim Bilimleri Enstitüsü, Konya.

Demirhan, S. (2012). Fen ve teknoloji öğretmenlerinin bilgi ve iletişim teknolojilerine ilişsin özyterlik algıları ve bilgi ve iletişim teknolojilerini kullanım durumları: Denizli ili örneği (Yayımlanmamış yüksek lisans tezi). Pamukkale ÜniversitesiEğitim Bilimleri Enstitüsü, Denizli.

Dikbaş, E. (2006). Öğretmen adaylarının e-öğrenmeye yönelik tutumlarının incelenmesi (Yayımlanmamış yüksek lisans tezi). Dokuz Eylül ÜniversitesiEğitim Bilimleri Enstitüsü, İzmir.

Eryılmaz, S. (2018). Öğrencilerin bilgi ve iletişim teknolojileri yeterliklerinin belirlenmesi: Gazi Üniversitesi, Turizm Fakültesi örneği. Elektronik Sosyal Bilimler Dergisi, 17(64), 37-49. https://doi.org/10.17755/esosder.310987

$\mathrm{Fu}$, J. S. (2013). ICT in Education: A critical literature review and its implications. International Journal of Education and Development Using Information and Communication Technology, 9(1), 112-125. Erişim adresi: https://eric.ed.gov/?id=EJ1182651

Göksoy, S. (2014). Hizmet içi eğitim faaliyetlerinin süreç ve sonuçlarının niteliğine yönelik öğretmen görüşleri. International Journal of Human Sciences, 11(1), 387-402. https://doi.org/10.14687/ijhs.v11i1.2645

Göktaş, Y., Yıldırım, Z. ve Yıldırım, S. (2008). Bilgi ve iletişim teknolojilerinin eğitim fakültelerindeki durumu: Dekanların görüşleri. Eğitim ve Bilim, 33(149), 30-50. Erişim adresi: http://egitimvebilim.ted.org.tr/index.php/EB/article/view/638/109

Güney, B. (2018). Sınıf ögretmenlerinin hizmetiçi eğitim programlarına ilişkin görüşleri: Mardin ili Midyat ilçesi örneği (Yayımlanmamış yüksek lisans tezi). İnönü Üniversitesi Eğitim Bilimleri Enstitüsü, Malatya.

Haznedar, Ö. (2012). Üniversite ögrencilerinin bilgi ve iletişim teknolojileri becerilerinin ve eögrrenmeye yönelik tutumlarının farklı değişkenler açısından incelenmesi (Yayımlanmamış yüksek lisans tezi). Dokuz Eylül Üniversitesi Eğitim Bilimleri Enstitüsü, İzmir.

He, J. veFreeman, L. A. (2010). Are men more technology-oriented than women? The role of gender on the development of general computer self-efficacy of college students. Journal of Information Systems Education, 21(2), 203-212. Erişim adresi: https://aisel.aisnet.org/jise/vol21/iss2/7/

Heerwegh, D., De Wit, K. veVerhoeven, J. (2016). Exploring the self-reported ICT skill levels of undergraduate science students. Journal of Information Technology Education, 15, 1947. https://doi.org/10.28945/2334

Hernandez Ramos, P. (2005). If not here, where? Understanding teachers' use of technology in Silicon Valley Schools. Journal of Research on Technology in Education, 38(1), 39-64. Retrieved from: https://files.eric.ed.gov/fulltext/EJ719937.pdf

Herzig, R. G. M. (2004). Technology and its impact in the classroom. Computers and Education, 42(2), 111-131. https://doi.org/10.1016/S0360-1315(03)00067-8

Hew, T. S. \&Leong, L. Y. (2011). An empirical analysis of Malaysian pre-university students' ICT competency gender differences. International Journal of Network and Mobile Technologies, 2(1), 15-29. Erişim adresi: https://pdfs.semanticscholar.org/a49e /fc06ad340207e2a3fcbd0a6b93e00d263864.pdf

International Society for Technology in Education. (2020). ISTE standards for educators. Erişim adresi: https://www.iste.org/standards/for-educators 
Kahyaoğlu, R. B. ve Karataş, S. (2019). Mesleki gelişim eğitim seminerlerine iliş̧in öğretmen görüşleri. Pamukkale Üniversitesi Sosyal Bilimler Enstitüsü Dergisi, 37, 191-220. https://doi.org/10.30794/pausbed.536050

Karadağ, R. (2015). Sınıf öğretmenlerinin Türkçe öğretimine yönelik hizmet içi eğitimlere ilişkin görüşleri ve hizmet içi eğitim gereksinimleri. İnönü Üniversitesi Eğitim Fakültesi Dergisi, 16(3), 33-50. https://doi.org/10.17679/iuefd.16380134

Karasar, N. (2015). Bilimsel araştırma yöntemleri: Kavramlar, ilkeler, teknikler (28. Bask1). Ankara: Nobel akademi yayınc1lık.

Koçak Usluel, Y., Kuşkaya Mumcu, F. ve Demiraslan, Y. (2007). Öğrenme öğretme sürecinde bilgi ve iletişim teknolojileri: Öğretmenlerin entegrasyon süreci ve engelleriyle ilgili görüşleri. Hacettepe Üniversitesi Eğitim Fakültesi Dergisi, 32, 164-178. Erişim adresi: http://www.efdergi.hacettepe.edu.tr/shw_artcl-588.html

Koçyiğit, M. ve Eğmir, E. (2019). Öğretmenlerin hizmet öncesi eğitim deneyimleri: Öğretmen yetiştirme üzerine bir analiz. Akdeniz Ĕ̈itim Araştırmaları Dergisi, 13(30), 320-346. https://doi.org/10.29329/mjer.2019.218.19

Koh, J.H.L. (2011). Computer skills instruction for pre-service teachers: A comparison of three instructional approaches. Computers in Human Behaviour, 27, 2392-2400. https://doi.org/10.1016/j.chb.2011.08.002

Kolburan Geçer, A. ve Gökdaş, İ. (2014). Öğretmenlerin bilgi ve iletişim teknolojilerinden yararlanma durumlarının bazı değişkenlere göre incelenmesi. Eğitim Bilimleri Araştırmaları Dergisi, 4(1), 89-112. http://dx.doi.org/10.12973/jesr.2014.41.5

Lim, C. P. ve Ching, C. S. (2004). An activity-theoretical approach to research of ICT integration in Singapore schools: Orienting activities and learner autonomy. Computers and Education, 43, 215-236. https://doi.org/10.1016/j.compedu.2003.10.005

Luu, K. ve Freeman, J. G. (2011). An analysis of the relationship between information and communication technology (ICT) and scientific literacy in Canada and Australia. Computers and Education, 56, 1072-1082. https://doi.org/10.1016/j. compedu.2010.11.008

Madden, T. (2003). Okul yöneticileri ve ögretmenler için düzenlenen hizmetiçi eğitim etkinliklerinin değerlendirilmesi: Eskişehir Ili (Yayımlanmamış yüksek lisans tezi). Anadolu ÜniversitesiEğitim Bilimleri Enstitüsü, Eskişehir.

Millî Eğitim Bakanlığı. (2017). Öğretmenlik mesleği genel yeterlikleri. Erişim Adresi: http://oygm.meb.gov.tr/www/ogretmenlik-meslegi-genel-yeterlikleri/icerik/39

Millî Eğitim Bakanlığı. (2018). Fırsatları artırma ve teknolojiyi iyileştirme hareketi (FATİH Projesi). Erişim adresi: http://fatihprojesi.meb.gov.tr/index.html

Millı̂ Eğitim Bakanlığı. (2019). Millı̂ Eğitim Bakanlığı 2018 yılı idare faaliyet raporu. Ankara Erişim adresi: http://sgb.meb.gov.tr/meb_iys_dosyalar/2019_03/01175437_MillY_ EYitim_BakanlYY_2018_YYlY_Ydare_Faaliyet_Raporu_YayYn2.pdf

Ormanc1, Ü. (2019). Investigation of pre-service teachers related to information and communication technologies skills. Online Science Education Journal, 4(2), 104-116. Erişim adresi: https://dergipark.org.tr/en/download/article-file/870325

Ozan, C. ve Taşgın, A. (2017). Öğretmen adaylarının eğitim teknolojisi standartlarına yönelik öz yeterliklerinin incelenmesi. Eğitim Teknolojisi Kuram ve Uygulama, 7(2), 236-253. Erişim adresi: https://dergipark.org.tr/en/download/article-file/323921

Özdemir, S. M., Akbaş, O. ve Çakır, R. (2009). A study on the relationship between pre-service teachers' information literacy skills and their attitudes towards distance education. Procedia Social and Behavioral Sciences, 1, 1648-1652. https://doi.org/10.1016/ j.sbspro.2009.01.291

Özel, A. (2010). Coğrafya derslerinde hangi bilgi ve iletişim teknolojileri nasıl kullanılmalı?R. Özey ve A. Demirci (Yay. Haz.), Coğrafya öğretiminde yöntem ve yaklaşımlar (ss. 233256) içinde. İstanbul: Aktif Yayınevi. 
Sanchez, J., Salinas, A. ve Haris, J. (2011). Education with ICT in South Korea and Chile. International Journal of Educational Development, 31, 126-148. https://doi.org/10.1016 /j.ijedudev.2010.03.003

Saygıner, Ş. (2016). Öğretmen adaylarının bilgisayar yeterlik düzeyleri ile teknolojiye yönelik algıları arasındaki ilişkinin çeşitli değişkenler açısından incelenmesi. Mustafa Kemal Üniversitesi Sosyal Bilimler Enstitüsü Dergisi, 13(34), 298-312. Erişim adresi: https://dergipark.org.tr/tr/download/article-file/226454

Sime, D. ve Priestly, M. (2005). Student teachers' first reflections on information and communications technology and classroom learning: Implications for initial teacher education. Journal of Computer Assisted Learning, 21, 130-142. https://doi.org/10.1111/j.1365-2729.2005.00120.x

$\mathrm{Su}, \mathrm{K}$. D. (2008). An integrated science course designed with information communication technologies to enhance university students' learning performance. Computers and Education, 51, 1365-1374. https://doi.org/10.1016/j.compedu.2007.12.002

Şad, S. N. ve Nalçac1, Ö. İ. (2015). Prospective teachers' perceived competencies about integrating information and communication technologies into education. Mersin University Journal of the Faculty of Education, 11(1), 177-197. https://doi.org/10.17860/efd.16986

Teo, T. (2009). Modelling technology acceptance in education: A study of pre- service teachers. Computers and Education, 52(2), 302-312. https://doi.org/10.1016/j.compedu. 2008.08.006

Tondeur, J., Aesaert, K., Pynoo, B., Braak, J. V., Fraeyman, N. ve Erstad, O. (2017). Developing a validated instrument to measure preservice teachers' ICT competencies: Meeting the demands of the 21st century. British Journal of Educational Technology, 48(2), 462-472. https://doi.org/10.1111/bjet.12380

Türk Dil Kurumu. (2020). Güncel Türkçe sözlük. Erişim adresi: www.sozluk.gov.tr

Türkiye İstatistik Kurumu. (2019). Bilgi toplumu istatistikleri. Erişim adresi: http://www.tuik.gov.tr/UstMenu.do?metod=temelist

Uluğ, F. (2000). İlköğretimde teknoloji eğitimi. Milli Ĕ̆itim Dergisi, 146, 3-8. Erişim adresi: https://dhgm.meb.gov.tr/yayimlar/dergiler/Milli_Egitim_Dergisi/146/ulug.htm

United Nations Educational Scientific and Qultural Organization. (2003). Developing and using indicators of ICT use in education.UNESCO Asia and Pacific Regional Bureau for Education, Bangkok, 7-9. Erişim adresi: https://unesdoc.unesco.org/ark:/48223 /pf0000131124

Usta, E. ve Korkmaz, Ö. (2010). Öğretmen adaylarının bilgisayar yeterlikleri ve teknoloji kullanımına ilişkin algıları ile öğretmenlik mesleğine yönelik tutumları. Uluslararası Insan Bilimleri Dergisi, 7(1), 1336-1349. Erişim adresi: https://docplayer.biz.tr 13738130-Ogretmen-adaylarinin-bilgisayar-yeterlikleri-ve-teknoloji-kullanimina-iliskinalgilari-ile-ogretmenlik-meslegine-yonelik-tutumlari.html

Ünal Bozcan, E. (2010). Eğitim öğretim faaliyetlerinde teknoloji kullanımı. Ĕgitim Teknolojileri Araştırmaları Dergisi, 1(4), 1-13. Erişim adresi: http://www.acarindex.com/dosyalar /makale/acarindex-1423877260.pdf

Yılmaz, M., Üredi, L. ve Akbaşlı, S. (2015). Sınıf öğretmeni adaylarının bilgisayar yeterlik düzeylerinin ve eğitimde teknoloji kullanımına yönelik algılarının belirlenmesi. International Journal of Humanities and Education, 1(1), 105-121. Erişim adresi: https://dergipark.org.tr/tr/pub/ijhe/issue/31784/348365

Yurdakul, I. K. (2011). Öğretmen adaylarının teknopedagojik eğitim yeterliklerinin bilgi ve iletişim teknolojilerini kullanımları açısından incelenmesi. Hacettepe Üniversitesi Eğitim Fakültesi Dergisi, 40, 397-408. Erişim adresi: http://efdergi.hacettepe.edu.tr /yonetim/icerik/makaleler/424-published.pdf

Yükseköğretim Kurulu. (2018). Öğretmen yetiştirme lisans programları. Ankara Üniversitesi Basımevi Müdürlüğü, Ankara. Erişim adresi: https://www.yok.gov.tr/kurumsal/idaribirimler/egitim-ogretim-dairesi/yeni-ogretmen-yetistirme-lisans-programlari 


\section{Extended Abstract}

\section{Introduction}

Information and communication technologies (ICT) are defined as all devices, tools, and settings used for information transmission, storage, production, reproduction, regulation, and sharing. People today should possess ICT skills because they are in every part of daily life (Şad \& Nalçac1, 2015) and important tools for solving everyday problems and interacting with the social environment (Sime \& Priestly, 2005). The ability of people to acquire ICT skills depends on numerous factors, one of the most important of which is educational institutions (Berkyürek, 2008; Demirhan, 2012; Eryılmaz, 2018; Göktaş, Yıldırım \& Yıldırım, 2008; Şad \& Nalçac1, 2015). Students from preschool to college have a long-term interaction with educational institutions. They are, therefore, expected to gain ICT knowledge and skills as well as a range of other knowledge and skills. In other words, educational institutions are responsible for providing students with an opportunity to develop ICT competencies required by the information age in accordance with the needs of society (Özel, 2010).

According to the International Society for Technology in Education (ISTE, 2020), ICT teachers should be technology literate educators who are capable of using technology in classrooms and encouraging students to use technology. The "General Competencies in Teaching Profession" section in the "Teacher Strategy Document" issued by the Ministry of National Education (2017b) stipulates that teachers should "use ICT effectively in the teaching and learning process." The Turkish Council of High Education (2018) also states that preservice teachers should possess ICT knowledge and skills. The teacher training undergraduate programs of the education faculties in Turkey were revised in 2018. With the revision, the "information technologies" and "teaching technologies" courses have been added as new compulsory courses to the curricula of twenty-five teaching training undergraduate programs in order to integrate ICT into teaching processes and to help preservice teachers develop ICT skills. Most courses, especially vocational knowledge and field education courses, already focus on ICT use (Higher Education Council, 2018).

Transforming students into effective teachers requires deliberate, planned, and applied training (Koçyiğit \& Ĕ̆mir, 2019). This suggests that studies on teacher quality should focus on preservice teachers. We can, therefore, state that this is an up-to-date study to investigate preservice teachers' ICT competencies. We believe that results will pave the way for further research on the issue and provide important information to teacher training institutions and their administrators and help them make necessary modifications and revisions to help preservice students to develop ICT competencies. The study sought answers to the following questions:

- What level of ICT competence do preservice teachers have?

- Do subscales, and gender, major, grade level, computer ownershipand attending seminars or courses have an effect on preservice teachers' ICT competencies?

\section{Method}

This was a quantitative research based on a survey model (Büyüköztürk, Kılıç Çakmak, Akgün, Karadeniz \& Demirel, 2015; Karasar, 2015). The sample consisted of 310 students of the department of the classroom and social studies teaching of the faculty of education of Ondokuz Mayis University in the fall semester of the 2019-2020 academic year. Participants were recruited using convenience sampling, which is a purposive sampling method. Data collection was a twostage process. The first stage involved the collection of information on the variables of major, gender, grade level, computer ownershipand attending seminars or courses on ICT. In the second stage, the Information and Communication Technology Competencies Scale for Preservice Teachers (ICTC-PT) developed by Tondeur et al. (2017) and adapted to Turkish language by Alkan and Emmioğlu Sarıkaya (2018) was used. Data were analyzed using frequency, percentage, arithmetic mean, and t-test and one-way variance analysis (ANOVA) for between-group 
comparisons. All statistical analysis were conducted using a data analysis software program at a significance level of .05 .

\section{Result and Discussion}

Participants had a high ICTC-PT total score and "competencies to support pupils for ICT-use in class" (CSP-ICT) subscale score whereas they had a moderate "competencies to use ICT for Instructional Design" (ICT-ID) subscale score. Research also shows that preservice teachers have higher education technology skills (Ormanc1, 2019; Ozan \& Taşgın, 2017) or consider themselves adequate about it (Yurdakul, 2011). Participants' scores did not significantly differ by major computer ownership. However, male participants had significantly higher CSP-ICT scores than females. Fourth graders had significantly higher CSP-ICT scores than other graders. Those who had attended seminars or courses on ICT had higher ICTC-PT and CSP-ICT scores than those who had not. Research also shows that male preservice teachers have higher ICT competence than female preservice teachers (Heerwegh, De Wit ve Verhoeven, 2016; Sayginer, 2016; Y1lmaz, Üredi ve Akbaşl1, 2015) and that the higher the grade level, the higher the ICT competence (Ormanc1, 2019). 